\title{
Photo Rechargeable Li-Ion Batteries using Nanorod Heterostructure Electrodes
}

Amar Kumar ${ }^{\mathrm{a}}$, Pallavi Thakur ${ }^{\mathrm{a}}$, Rahul Sharma ${ }^{\mathrm{a}}$, Anand Puthirath ${ }^{\mathrm{b}}$, Pulickel M. Ajayan ${ }^{\mathrm{b}}$, and Tharangattu N. Narayanan ${ }^{\mathrm{a}^{*}}$

a Tata Institute of Fundamental Research - Hyderabad, Hyderabad, Telangana 500046, India

${ }^{\mathrm{b}}$ Department of Materials Science and Nano-engineering, Rice University, Houston, Texas 77005, United States

(Email*: tnn@tifrh.res.in) 


\section{$\underline{\text { ToC }}$}

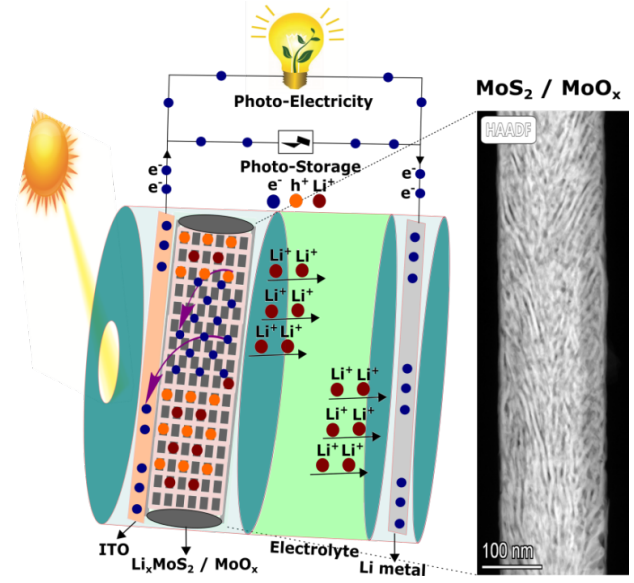

The working (photo-charging) of single nanorod containing $\mathrm{MoS}_{2} / \mathrm{MoO}_{\mathrm{x}}$ heterostructure based two-electrode solar battery. A high-resolution high angle annual dark-field image of the nanorod is also shown indicating the structure containing both amorphous and crystalline regions. 
Abstract: New ways of directly using solar energy to charge electrochemical energy storage devices such as batteries would lead to exciting developments in energy technologies. Here, a two-electrode photo-rechargeable Li-ion battery is demonstrated using nanorod of type II semiconductor heterostructures with in-plane domains of crystalline $\mathrm{MoS}_{2}$ and amorphous $\mathrm{MoO}_{\mathrm{x}}$. The staggered energy band alignment of $\mathrm{MoS}_{2}$ and $\mathrm{MoO}_{\mathrm{x}}$ limits the electron holes recombination and cause holes to be retained in the Li intercalated $\mathrm{MoS}_{2}$ electrode. The holes generated in the $\mathrm{MoS}_{2}$ pushes the intercalated $\mathrm{Li}^{+}$ions and hence, charge the cell. Low band gap, high efficiency photo-conversion and efficient electron-hole separation help the battery to fully charge within a few hours with a low power light. The proposed concept and materials could enable next generation stable solar chargeable battery electrodes, in contrast to the reported materials.

Keywords: Solar battery; Li-ion battery; Type II Semiconductor Heterostructure; $\mathrm{MoS}_{2} ; \mathrm{MoO}_{\mathrm{x}}$. 


\section{Introduction:}

A fully photo rechargeable Li-ion batteries would revolutionize today's energy conversion/storage paradigm. Two electrode solar cells are typically used to store solar energy where solar energy is first converted to electricity which is, then, stored in a conventional two electrode battery. ${ }^{1}$ The inherent limitation of this process is the weight caused by a solar cell stack since a maximum voltage which can be delivered by a single junction solar cell is $\sim 0.6-1.0$ $\mathrm{V}$ only, which is insufficient for electrochemical storage systems such as Li-ion batteries. ${ }^{2}$ Further, this whole process involves two conversion steps: conversion of solar energy to electricity by solar cell and the electricity conversion as electrochemical energy in a battery. Two separate systems having four electrodes cause large conversion loss and also increase the overall intricacy, weight, and cost. ${ }^{3}$ Highly efficient, low-cost, compact, and light-weight solar energy storage systems are of high demand in sectors of different kinds, such as in high energy density demand portable devices, solar vehicles, solar impulse planes, satellites, etc. ${ }^{4,5,6}$

This concept was initially proposed by Hodes et. al. in 1976, where they have shown a three-electrode system comprised of cadmium selenide, sulfur, and silver sulphide $\left(\mathrm{CdSe} / \mathrm{S} / \mathrm{Ag}_{2} \mathrm{~S}\right){ }^{7}$ In this system, one of the components was acted as photo-electrode while others as the components for the energy storage. Such effortshave continued with other threeelectrode systems, such as n-cadmium selenide telluride/cesiumsulfide/tin sulfide ${ }^{8}$ and hybrid Titania $\left(\mathrm{TiO}_{2}\right)$ poly(3,4-ethylenedioxythiophene) as photo anode and a perchlorate $\left(\mathrm{ClO}_{4}^{-}{ }^{-}{ }^{-}\right.$ doped polypyrrole counter electrode.

This approach was improved by using a two-electrode system with a hybrid mixture of lithium iron phosphate (LFP) nanocrystals and N719 dye as the active photo-electrode assembled 
with lithium metal as counter electrode. ${ }^{9}$ The N719 dye acts as photon absorber and LFP as cathode. In this system, during the photo-charging, the electrons produced during the photoexcitation of the dye generate holes in the valance band which repel $\mathrm{Li}^{+}$ions from their intercalated state. The continuous photo-conversion drives the battery to reach back in the charged state (in 30 hours (hr) with $200 \mathrm{~W}$ solar spectrum (simulator)). ${ }^{9}$ But the LFP-N719 hybrid system provided a photo-conversion efficiency of $\sim 0.06 \%$ only. ${ }^{9}$ Further it was observed that soon after the first cycle, the charge capacity started fading due to dissolution of the organic dye in to the organic electrolyte.

A different approach was attempted where a polycrystalline metal halide based 2D perovskite was used as a photo-active electrode $\left(\left(\mathrm{C}_{6} \mathrm{H}_{9} \mathrm{C}_{2} \mathrm{H}_{4} \mathrm{NH}_{3}\right)_{2} \mathrm{PbI}_{4}\right)$ that could provide both the energy storage (battery functionality) and the photo charging (photovoltaic functionality) together. ${ }^{10}$ This perovskite system provided a low photo conversion efficiency of $\sim 0.034 \%$. Further, the system suffered from various other challenges such as the conversion reaction between lithium and perovskite generating lead $(\mathrm{Pb})$ where it can further make alloy with lithium causing large volume expansion.

More recently it was reported that organic molecule based photo-electrode could be used for photo-charging. ${ }^{11}$ Absorption of light of a desired wavelength by lithiated tetrakislawsone electrodes generates electron-hole pairs. The holes oxidize the lithiated tetrakislawsone to tetrakislawsone while the generated electrons flow from the tetrakislawsone cathode to the $\mathrm{Li}$ metal anode through outer circuit. Authors showed $\sim 12 \%$ increase in discharge capacity due to competitive charging in the presence of light. Yet the dissolution of organic molecule in organic 
solvents used in the electrolytes limits its long-term performance. Further, tetrakislawsone absorbs only violet light which is a minor component of the entire solar spectrum.

Semiconductors possess well defined band gaps and they can be tuned to make heterostructures with other semiconductors having different band gaps resulting in the separation of photo-excited electron-hole pairs. ${ }^{12,13}$ Further, some of these semiconductors have layered structure where they can be employed as active cathode or anode materials for different metal ion battery systems such as $\mathrm{Li}^{+}, \mathrm{Na}^{+}, \mathrm{K}^{+}$, etc. Such semiconductors include oxides and sulphides such as $\mathrm{TiS}_{2}, \mathrm{MoO}_{3}, \mathrm{MoS}_{2}, \mathrm{TiO}_{2}$ etc. ${ }^{14,15,16,17,18,19}$ They have been shown to exhibit high stable energy capacity (300-1000 mAh $\left.\mathrm{g}^{-1}\right)$ for many cycles of operation when used in conventional metal-ion battery systems. By virtue of their two-dimensional (2D) structure in isolated form, they can also be used for thin- batteries. Further, heterostructures of these 2D materials show high energy capacity as compared to conventional $2 \mathrm{D}$ material. ${ }^{20}$

Photo-excited electron-hole separation is a bottleneck in any semiconductor as the high exciton binding energy and fast recombination can inhibit the photo-recharging process. A typeII semiconductor heterostructure (having staggered band alignment) of two different semiconductors can effectively separate the generated electron-hole pairs. ${ }^{21}$ In this case, after the excitation, all the electrons get accumulated in the low energy conduction band of one semiconductor while the holes get transferred to the high energy valence band of the second semiconductor. ${ }^{21}$ Further, nanostructured light absorbers have advantages such as shortening of carrier collection pathways along with improved light distribution. ${ }^{22}$ Such an architecture provides large the surface area for $\mathrm{Li}^{+}$ion diffusion and control over the volume expansion during cycling. ${ }^{23}$ 
Here, we propose such a novel heterostructure of $\mathrm{MoS}_{2} / \mathrm{MoO}_{\mathrm{x}}$ nanorod (NR) as a single nanostructured electrode for two electrode photo-rechargeable Li-ion battery. The crystalline $\mathrm{MoS}_{2}$ acts as $\mathrm{Li}^{+}$intercalating electrode where on photoexcitation holes remain in the matrix while the electrons get transferred to $\mathrm{MoO}_{3}$ and then to the current collector via the conductive carbon matrix. The mechanism of charge separation is initially proven using photocurrent measurements followed by the demonstration of a photo-rechargeable cell of $\mathrm{Li}^{+}$, where photocharging and extending the discharge time using light are demonstrated. Ahigh surface area photo-active $\mathrm{Li}^{+}$intercalable electrode is developed. $\mathrm{MoO}_{3}$ nanorods are initially synthesized by a hydrothermal method, reported elsewhere ${ }^{24}$ followed by their partial surface sulfurization by a chemical vapour transport deposition (CVD) method to grow nanostructured $\mathrm{MoS}_{2}$ regions (detailed in method section-1). In a partially sulfurized $\mathrm{MoO}_{3}$ i.e. $\mathrm{MoS}_{2} / \mathrm{MoO}_{\mathrm{x}}\left(\mathrm{MoO}_{\mathrm{x}}\right.$ nomenclature is established later) nanorods, both $\mathrm{MoS}_{2}$ and $\mathrm{MoO}_{3}$ are exposed at the surface. $\mathrm{MoS}_{2}$ has higher exposed surface area compared to that of $\mathrm{MoO}_{\mathrm{x}}$, which is confirmed by scanning transmission electron microscopy (STEM) and high angle annular dark field (HAADF) analyses, discussed in the later part. Covalently attached $\mathrm{MoS}_{2}$ with $\mathrm{MoO}_{\mathrm{x}}$ domains in $\mathrm{MoS}_{2} / \mathrm{MoO}_{\mathrm{x}}$ structure can offer high light-matter interaction and high intercalation area for $\mathrm{Li}^{+}$, and hence without causing the mass transfer limitations in the electrochemical lithiation/delithiation processes. 


\section{Results and discussion:}

(a) Structure and Chemical Nature of $\mathrm{MoS}_{2} / \mathrm{MoO}_{x} \mathrm{NRs}$ :

The morphology of the photo-active electrode plays an important role in attaining the high photo-conversion efficiency. Maximal surface area of the heterostructure should be exposed to the light, and electrons should be easily transferrable to the outer circuit after they get accumulated in the low energy conduction band of the heterostructure. As mentioned before, orthorhombic $\alpha-\mathrm{MoO}_{3}$ nanorods (NR) were synthesized via a hydrothermal process (figure 1(a)). ${ }^{24}$ A partial sulfurization of $\mathrm{MoO}_{3}$ surface by a CVD technique (details in method section-1 SI) is then conducted. For comparison, the $\mathrm{MoO}_{3}$ NRs were completely sulfurized and converted to $\mathrm{MoS}_{2} \mathrm{NRs}$ as well, by the same procedure employing longer growth time (figure 1 (a)).

The structure and morphology of all the three samples $\mathrm{MoO}_{3} \mathrm{NR}, \mathrm{MoS}_{2} \mathrm{NR}$, and the $\mathrm{MoS}_{2} / \mathrm{MoO}_{\mathrm{x}} \mathrm{NR}$ were confirmed by scanning electron microscopy (SEM) imaging (figure S1). All the samples possess porous nanorod morphology with an average size of $\sim 200 \mathrm{~nm}$ diameter and 1-2 $\mu \mathrm{m}$ length. Furthermore, the energy dispersive spectroscopy (EDS) based elemental mapping shows the uniform distribution of molybdenum and oxygen in $\mathrm{MoO}_{3} \mathrm{NR}$, molybdenum and sulphur in $\mathrm{MoS}_{2} \mathrm{NR}$ whereas molybdenum, oxygen, and sulphur in $\mathrm{MoS}_{2} / \mathrm{MoO}_{\mathrm{x}} \mathrm{NR}$ (figure S1), indicating the formation of the chemical structure as assigned.

To further confirm the chemical structure of NRs, Raman spectroscopy analysis was carried out. Raman spectrum of the $\mathrm{MoO}_{3} \mathrm{NR}$ (figure 1 (b), blue curve) shows the following vibrational modes: at $156 \mathrm{~cm}^{-1}\left(\mathrm{Ag}_{\mathrm{g}}, \mathrm{B}_{1 \mathrm{~g}}\right)$ originating from the translation of the rigid chains, at $290 \mathrm{~cm}^{-1}\left(\mathrm{~B}_{2 \mathrm{~g}}, \mathrm{~B}_{3 \mathrm{~g}}\right)$ a doublet comprised of wagging modes of the terminal oxygen atoms, at 
$666.5 \mathrm{~cm}^{-1}\left(\mathrm{~B}_{2 \mathrm{~g}}, \mathrm{~B}_{3 \mathrm{~g}}\right)$ corresponds to the asymmetric stretching of the Mo-O-Mo bridge along the $\mathrm{c}$ axis, at $820 \mathrm{~cm}^{-1}\left(\mathrm{~A}_{\mathrm{g}}, \mathrm{B}_{1 \mathrm{~g}}\right)$ is a symmetric stretch of the terminal oxygen atoms, and at 995 $\mathrm{cm}^{-1}\left(\mathrm{~A}_{\mathrm{g}}, \mathrm{B}_{1 \mathrm{~g}}\right)$ is the asymmetric stretch of the terminal oxygen atoms. ${ }^{25}$ This confirms the formation of $\mathrm{MoO}_{3}$. The Raman spectrum of $\mathrm{MoS}_{2} \mathrm{NR}$ shows vibrational modes correspond to that of $E_{2 g}\left(379 \mathrm{~cm}^{-1}\right)$ and $A_{1 g}\left(405 \mathrm{~cm}^{-1}\right)$, figure 1 (b), black curve. This shows the typical behaviour of bulk $2 \mathrm{H}-\mathrm{MoS}_{2}{ }^{26}$ Hence, it confirms the conversion of $\mathrm{MoO}_{3}$ to $\mathrm{MoS}_{2}$ nanorods with bulk characteristics. Subsequently, characteristics modes of vibration for both the components i.e. $\mathrm{MoO}_{3}$ and $\mathrm{MoS}_{2}$, were observed in partially sulfurized $\mathrm{MoO}_{3}$ nanorods $\left(\mathrm{MoS}_{2} / \mathrm{MoO}_{\mathrm{x}} \mathrm{NR}\right.$, figure 1 (b), red curve). However, the Raman shifts corresponding to $\mathrm{E}_{2 \mathrm{~g}}(380$ $\left.\mathrm{cm}^{-1}\right)$ and $\mathrm{A}_{1 \mathrm{~g}}\left(403 \mathrm{~cm}^{-1}\right)$ modes of vibration in $\mathrm{MoS}_{2} / \mathrm{MoO}_{\mathrm{x}} \mathrm{NR}$ are red shifted by $\sim 2 \mathrm{~cm}^{-1}$ in comparison to that in $\mathrm{MoS}_{2}$ NRs (figure S2 (a)). This indicates the presence of a few layered $\mathrm{MoS}_{2}$ on $\mathrm{MoO}_{3}$ nanorods. ${ }^{27}$ Furthermore, broadening in the $\mathrm{MoO}_{3}$ Raman modes in $\mathrm{MoS}_{2} / \mathrm{MoO}_{\mathrm{x}}$ NR shows the possibilities of oxygen vacancies generated in $\mathrm{MoO}_{3}$ forming $\mathrm{MoO}_{\mathrm{x}}$ (Figure S2 (b)) ${ }^{28}$

Furthermore, X-Ray Photoelectron spectroscopy (XPS) analysis was performed to study the oxidation states of the atoms in each NRs. The XPS survey spectra (figure 1 (c)) of the samples confirm the presence of $\mathrm{Mo}(3 \mathrm{~d})$ and $\mathrm{O}(1 \mathrm{~s})$ in $\mathrm{MoO}_{3} \mathrm{NR}$, Mo (3d) and $\mathrm{S}(2 \mathrm{p})$ in $\mathrm{MoS}_{2}$ NR while all the three elements, Mo (3d), O (1s), and S (2p), in $\mathrm{MoS}_{2} / \mathrm{MoO}_{\mathrm{x}} \mathrm{NR}$.

The high resolution XPS spectra of each of the elements were collected from all the samples. For $\mathrm{MoO}_{3} \mathrm{NR}$, Mo 3d shows two peaks positioned at $231.3 \mathrm{eV}$ and $234.4 \mathrm{eV}$ (Figure S3 (a)), arising due to spin-orbit splitting of Mo 3d5/2 and Mo 3d3/2, respectively. This indicates the presence of $\mathrm{Mo}^{6+}$ chemical state. The binding energy (BE) peak at $529.10 \mathrm{eV}$ (Figure S3 (d)) 
is ascribed to $\mathrm{O} 1 \mathrm{~s}$ of $\mathrm{MoO}_{3}$. This corroborates the formation of molybdenum trioxide $\left(\mathrm{MoO}_{3}\right)$ nanorods.

In $\mathrm{MoS}_{2} \mathrm{NR}$, four distinct peaks (Figure S3 (c)) are observed for Mo 3d, they correspond to that of $\mathrm{Mo}^{4+}$ and $\mathrm{Mo}^{5+}$ chemical states. Two peaks at the BEs of $228.0 \mathrm{eV}$ and $231.0 \mathrm{eV}$ correspond to $\mathrm{Mo}^{4+}$ while the other two at the BEs of $229.2 \mathrm{eV}$ and $232.0 \mathrm{eV}$ correspond to $\mathrm{Mo}^{5+}$ chemical state (all the peaks are normalised by C $1 \mathrm{~s} \mathrm{peak)}{ }^{29}$ The peak at $225.5 \mathrm{eV}$ relates to the S $2 \mathrm{~s}$ of $\mathrm{MoS}_{2}$. In addition to this, S $2 \mathrm{p}$ peak (Figure S3 (f)) is fitted with three peaks that correspond to $\mathrm{S} 2 \mathrm{p} 3 / 2$ at $160.7 \mathrm{eV}, \mathrm{S} 2 \mathrm{p} 1 / 2$ at $162.0 \mathrm{eV}$, and edge $\mathrm{S}$ at $163.3 \mathrm{eV} .{ }^{30}$

The high resolution XPS spectra of Mo 3d for $\mathrm{MoS}_{2} / \mathrm{MoO}_{\mathrm{x}} \mathrm{NR}$ (Figure S3 (b)) also show four peaks. Here, the two peaks positioned at the BEs of $229.1 \mathrm{eV}$ and $232.2 \mathrm{eV}$ are indicating the presence of $\mathrm{Mo}^{5+}$ chemical state as in $\mathrm{MoS}_{2},{ }^{31}$ while the other two low intensity broad peaks at the $\mathrm{BEs}$ of $230.6 \mathrm{eV}$ and $234.0 \mathrm{eV}$ indicate the presence of $\mathrm{Mo}^{6+}$ chemical state. A small shift in $\mathrm{BE}$ for $\mathrm{Mo}^{6+} 3 \mathrm{~d} 5 / 2$ is due to signals from lower oxidation $\left(\mathrm{Mo}^{5+}\right)$ state which are tailing in lower binding energy. ${ }^{29}$

The O 1s in $\mathrm{MoS}_{2} / \mathrm{MoO}_{\mathrm{x}} \mathrm{NR}$ (Figure S3 (e)) shows two peaks at the BEs of $529.9 \mathrm{eV}$ and $531.2 \mathrm{eV}$, indicating the presence of metal oxide $\mathrm{O} 1 \mathrm{~s}$ and sub-oxide, respectively. Hence, the heterostructure has mixture of molybdenum oxides and suboxides $\left(\mathrm{MoO}_{\mathrm{x}}\right)$. These suboxides impart better conductivity and improve the charge transfer. ${ }^{12}$ The signals at the BEs $226.3 \mathrm{eV}$, $161.9 \mathrm{eV}$, and $163.1 \mathrm{eV}$ are corresponding to $\mathrm{S} 2 \mathrm{~s}, \mathrm{~S} 2 \mathrm{p} 3 / 2$, and $\mathrm{S} 2 \mathrm{p} 1 / 2$, respectively (Figure $\mathrm{S} 3$ $(\mathrm{g}))$. 


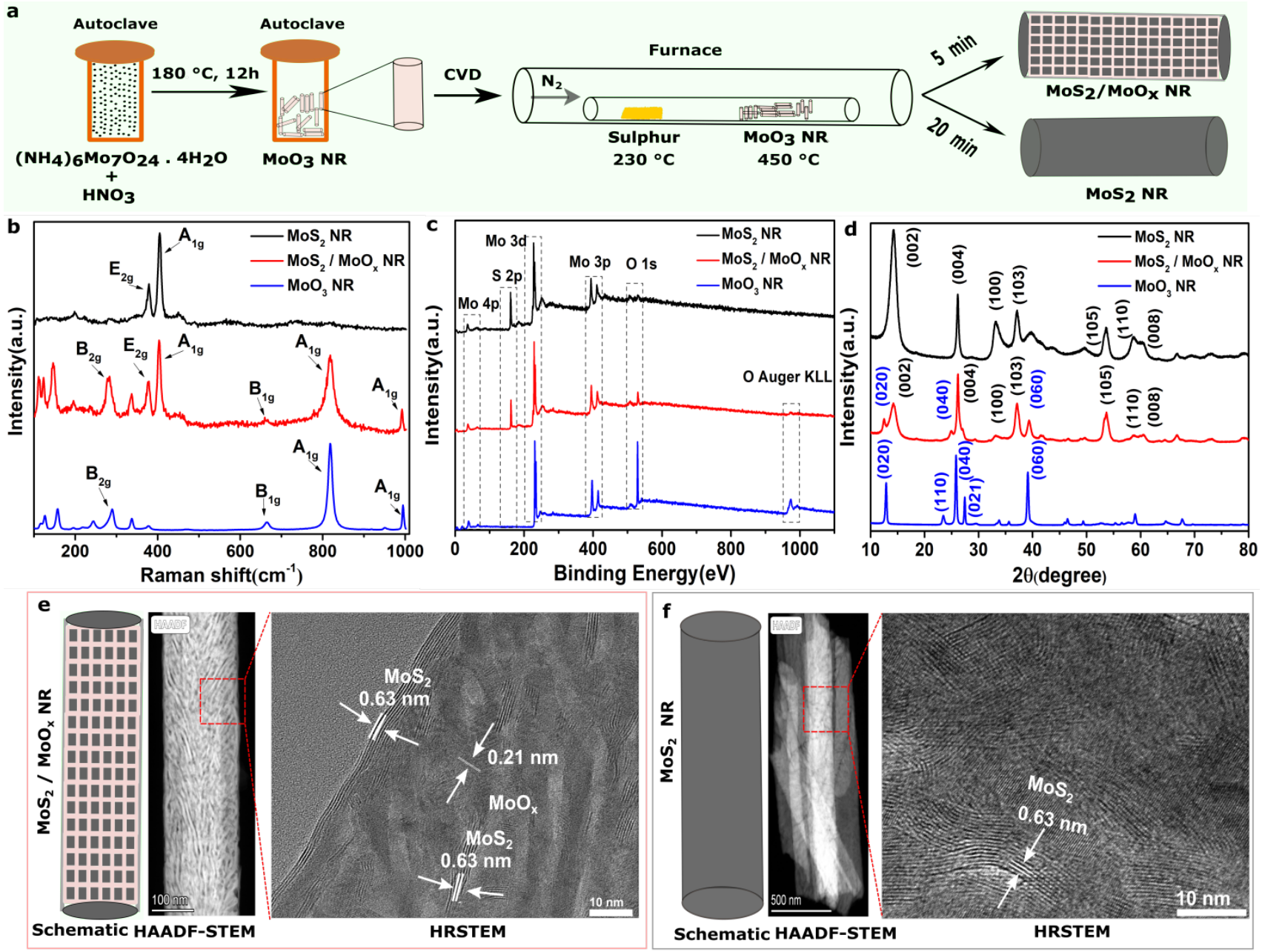

Figure 1. (a) Schematic of the reaction procedure for the synthesis of $\mathrm{MoO}_{3}$ NRs, heterostructured $\mathrm{MoS}_{2} / \mathrm{MoO}_{\mathrm{x}} \mathrm{NRs}$, and $\mathrm{MoS}_{2}$ NRs. The characterisations of $\mathrm{MoO}_{3} \mathrm{NR}, \mathrm{MoS}_{2} / \mathrm{MoO}_{\mathrm{x}}$ NR, and $\mathrm{MoS}_{2}$ NR using (b) Raman analysis, (c) XPS survey scan, and (d) XRD, indicating their characteristic features as explained. STEM and HAADF images of, (e) $\mathrm{MoS}_{2} / \mathrm{MoO}_{\mathrm{x}} \mathrm{NR}$ and (f) $\mathrm{MoS}_{2} \mathrm{NR}$ along with their schematics of the structures.

The crystalline structure of all the samples was studied using by powder X-ray diffraction (XRD) technique (Figure 1 (d)). Diffraction peaks for $\mathrm{MoO}_{3} \mathrm{NR}$ (blue) indicates that of the pure $\alpha-\mathrm{MoO}_{3}$ crystalline phase. ${ }^{32}$ The diffraction peaks of $\mathrm{MoS}_{2} \mathrm{NR}$ (black) can be indexed as (002), (004), (100), (103), (105), (110), and (008) planes of hexagonal MoS 2 crystal. ${ }^{33}$ However, the 
diffraction peaks corresponding to only (0k0) planes of $\mathrm{MoO}_{3}$ are found in $\mathrm{MoS}_{2} / \mathrm{MoO}_{\mathrm{x}}$ hybrid structure. Some of the crystalline planes of $\alpha-\mathrm{MoO}_{3}$ have converted to amorphous $\alpha-\mathrm{MoO}_{3}$ during the sulfurization process. This conversion is already confirmed by XPS analysis of $\mathrm{MoS}_{2} /$ $\mathrm{MoO}_{\mathrm{x}}$ NR.

STEM analysis was also carried out on all the three samples. In the STEM-HAADF image, various bright and dark phases were observed on the surface of $\mathrm{MoS}_{2} / \mathrm{MoO}_{\mathrm{x}} \mathrm{NR}$ (figure 1 (e)) (additional information in figure S4). The bright phase corresponds to that of $\mathrm{MoS}_{2}$ as it is more crystalline compared to the $\mathrm{MoO}_{\mathrm{x}}$ in corroboration with the XRD analysis. The HRSTEM images show the inter planar distance of $0.63 \mathrm{~nm}$, belongs to the crystalline $\mathrm{MoS}_{2} .{ }^{34}$ While the $\mathrm{MoO}_{3}$ has converted to mix-oxides $\left(\mathrm{MoO}_{\mathrm{x}}\right)$. An interplanar spacing of $0.21 \mathrm{~nm}$ (corresponds to (002)) is observed for $\mathrm{MoO}_{\mathrm{x}}$ which is slightly higher than the reported oxygen vacancies containing $\mathrm{MoO}_{\mathrm{x}}{ }^{35}$ Thus, in $\mathrm{MoS}_{2} / \mathrm{MoO}_{\mathrm{x}} \mathrm{NRs}$, a few layered crystalline $\mathrm{MoS}_{2}$ sheets are distributed over the molybdenum mix-oxides $\left(\mathrm{MoO}_{\mathrm{x}}\right)$ nanorods.

(b) UV Absorption and Photocurrent Measurements:

In order to efficiently separate the photoinduced carriers, a rational design of semiconductor heterostructure is highly needed. It includes narrowing the band gap and better separation of electron hole pair. In this study, the staggered band position of $\mathrm{MoS}_{2} / \mathrm{MoO}_{\mathrm{x}}$ system facilitates a better electron-hole separation on the absorption of light (figure 2 (a) and further details of band alignment in supporting information, section-3).

The absorption spectra of all the three samples were studied using UV-Vis spectroscopy technique. The powder samples were dispersed in ethanol for the absorption measurements. 
$\mathrm{MoO}_{3} \mathrm{NR}$ shows absorption edge at $438 \mathrm{~nm}$ and absorption maximum at $300 \mathrm{~nm}^{36}$ while $\mathrm{MoS}_{2}$ NR shows absorptions at $647 \mathrm{~nm}$ and $707 \mathrm{~nm}$ (figure 2 (b)). ${ }^{37}$ However, in $\mathrm{MoS}_{2} / \mathrm{MoO}_{\mathrm{x}} \mathrm{NR}$, the absorption maximum is blue-shifted as compared to the bulk $\mathrm{MoS}_{2}$ due to the presence of only a few layers of $\mathrm{MoS}_{2}$ present over $\mathrm{MoO}_{\mathrm{x}}$ (figure 2 (b), red curve). ${ }^{37}$ An additional absorption maximum at $496 \mathrm{~nm}$ is also observed due to oxygen vacancies in $\mathrm{MoO}_{\mathrm{x}} .{ }^{35}$ This further confirms the oxygen vacancies produced in $\mathrm{MoO}_{\mathrm{x}}$.

In order to charge a photo-rechargeable battery, a large number of photo-electron generation is utmost important. Therefore, photo-response of the active material $\left(\mathrm{MoS}_{2} / \mathrm{MoO}_{\mathrm{x}}\right.$ $\mathrm{NR}$ ) was tested in $0.1 \mathrm{M} \mathrm{Na}_{2} \mathrm{SO}_{4}$ solution after coated on a glassy carbon electrode with an applied bias voltage of $0.3 \mathrm{~V}$ vs $\mathrm{Ag} / \mathrm{AgCl}$ reference electrode. The photo-response was tested with a green light source (using an LED of $533 \mathrm{~nm}$ and $50 \mathrm{~mW}$ ) and a red light source (an LED of $633 \mathrm{~nm}, 50 \mathrm{~mW}$ ), as the white light contains maximum of these wavelengths' contribution. ${ }^{38}$ 


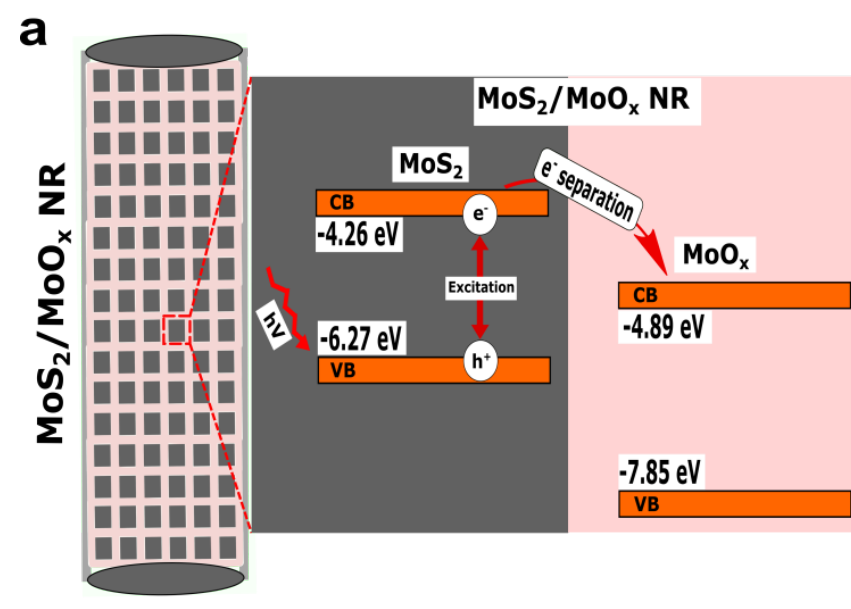

b

C
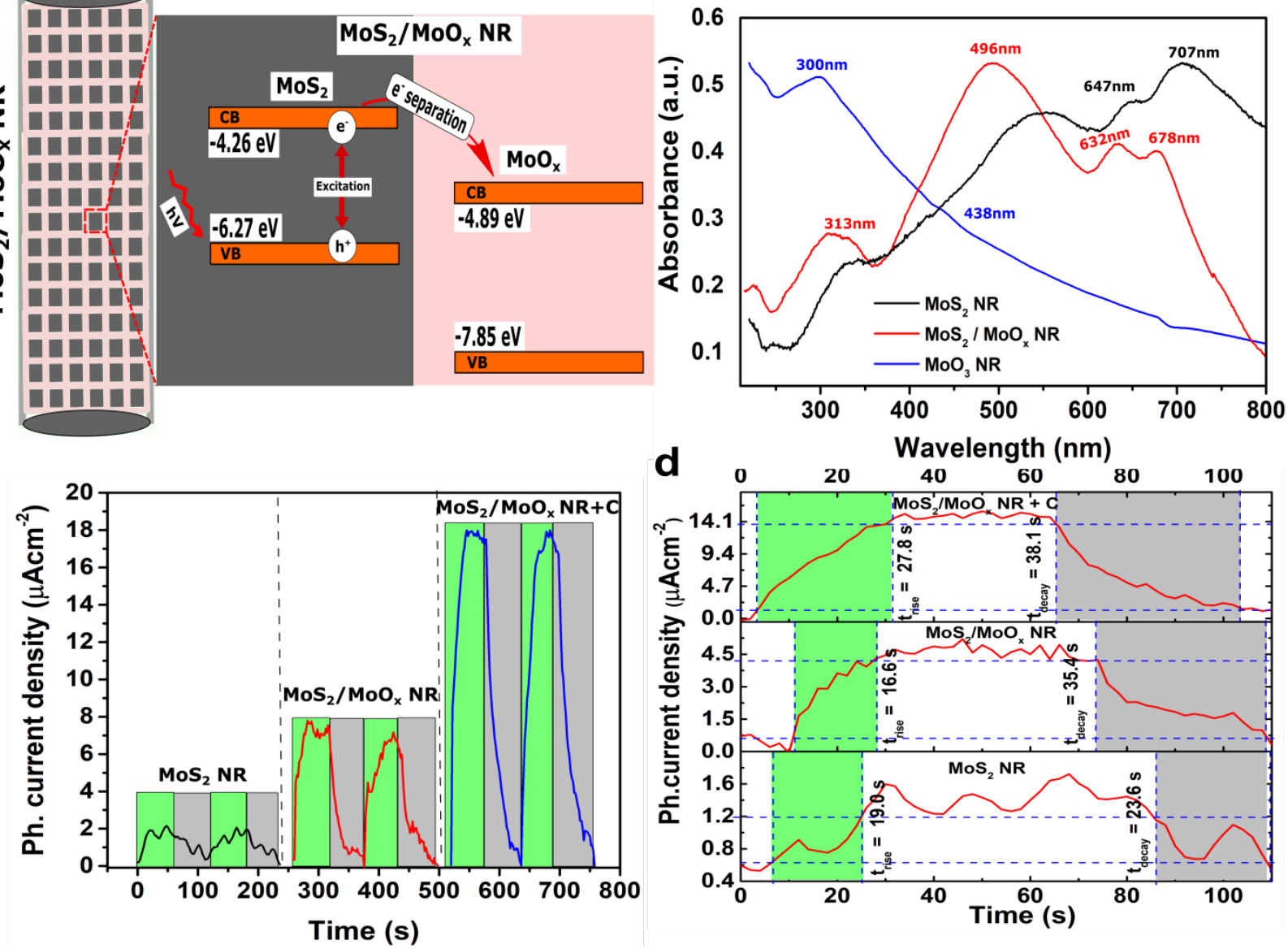

Figure 2. Optical response and charge transfer mechanism:

(a) schematic electron-hole separation in the heterostructure $\mathrm{MoS}_{2} / \mathrm{MoO}_{\mathrm{x}} \mathrm{NR}$ (black-MoS , light pink-MoOx). (b) The UVVis spectra of $\mathrm{MoO}_{3}$ (blue curve), heterostructure $\mathrm{MoS}_{2} / \mathrm{MoO}_{\mathrm{x}} \mathrm{NR}$ (red curve), and $\mathrm{MoS}_{2} \mathrm{NR}$ (black curve). (c) Comparison of the photoresponses of $\mathrm{MoS}_{2}$ (black curve), $\mathrm{MoS}_{2} / \mathrm{MoO}_{\mathrm{x}} \mathrm{NR}$, (red curve) and $\mathrm{MoS}_{2} / \mathrm{MoO}_{\mathrm{x}} \mathrm{NR}+\mathrm{C}$ black (blue curve) at $\mathrm{V}=0.3 \mathrm{~V}$ vs $\mathrm{Ag} / \mathrm{AgCl}$ and power density $50 \mathrm{~mW} / \mathrm{cm}^{-2}$. (d) Comparison of photocurrent rise time and decay time of $\mathrm{MoS}_{2}$, $\mathrm{MoS}_{2} / \mathrm{MoO}_{\mathrm{x}} \mathrm{NR}$ and $\mathrm{MoS}_{2} / \mathrm{MoO}_{\mathrm{x}} \mathrm{NR}+\mathrm{C}$ black.

As suggested by UV-Visible absorption spectra, there is no (negligible) absorption from $\mathrm{MoO}_{3} \mathrm{NR}$ in this frequency range since its absorption edge is at $\sim 438 \mathrm{~nm}$. The photoresponses of $\mathrm{MoS}_{2} \mathrm{NR}, \mathrm{MoS}_{2} / \mathrm{MoO}_{\mathrm{x}} \mathrm{NR}$, and $\mathrm{MoS}_{2} / \mathrm{MoO}_{\mathrm{x}} \mathrm{NR}+\mathrm{C}$ black (the performance in the presence of 
C- black is also tested because it is added with the active material during electrode fabrication for the battery) are measured, figure 2(c). The $\mathrm{MoS}_{2} / \mathrm{MoO}_{\mathrm{x}} \mathrm{NR}+\mathrm{C}$ showed the highest photocurrent density $\left(\sim 17 \mu \mathrm{A} / \mathrm{cm}^{2}\right)$ followed by $\mathrm{MoS}_{2} / \mathrm{MoO}_{\mathrm{x}}\left(\sim 8 \mu \mathrm{A} / \mathrm{cm}^{2}\right)$, and $\mathrm{MoS}_{2}\left(<2 \mu \mathrm{A} / \mathrm{cm}^{2}\right)$. This significant photocurrent difference between $\mathrm{MoS}_{2} / \mathrm{MoO}_{\mathrm{x}} \mathrm{NR}$ and $\mathrm{MoS}_{2} \mathrm{NR}$ clearly shows that the heterojunction of $\mathrm{MoS}_{2} / \mathrm{MoO}_{\mathrm{x}} \mathrm{NR}$ helps in the charge separation of excitons formed during the light exposure because of the type II nature of the junction, as explained in figure 2 (a). The photoresponsivity is calculated with the formula $R_{\lambda}=\frac{I_{p h}}{P A}$, where R $\mathrm{R}_{\lambda}$ is the photoresponsivity, $\mathrm{I}_{\mathrm{Ph}}$ is the photocurrent, $P$ is the power density, and $\mathrm{A}$ is the effective area of the device. The photoresponsivity for $\mathrm{MoS}_{2} \mathrm{NR}, \mathrm{MoS}_{2} / \mathrm{MoO}_{\mathrm{x}} \mathrm{NR}$, and $\mathrm{MoS}_{2} / \mathrm{MoO}_{\mathrm{x}} \mathrm{NR}+\mathrm{C}$ are calculated as $0.03,0.15$, and $0.32 \mathrm{~mA} / \mathrm{W}$, respectively. Low photoresponsivity of $\mathrm{MoS}_{2} \mathrm{NR}$ shows lack of photogenerated free charge carriers due to exciton formation. Figure 2(d) shows the measurement of response time of different systems. The response time for $\mathrm{MoS}_{2} \mathrm{NR}$ and $\mathrm{MoS}_{2} / \mathrm{MoO}_{\mathrm{x}} \mathrm{NR}$ are $\sim 19 \mathrm{~s}$ and $\sim 16.8 \mathrm{~s}$, respectively. Relatively faster response time in $\mathrm{MoS}_{2} / \mathrm{MoO}_{\mathrm{x}}$ NR compared to $\mathrm{MoS}_{2} \mathrm{NR}$ shows a clean interface between $\mathrm{MoS}_{2}$ and $\mathrm{MoO}_{\mathrm{x}}$ layers which is already evident from the STEM analyses. The $\mathrm{MoS}_{2} / \mathrm{MoO}_{\mathrm{x}} \mathrm{NR}+\mathrm{C}$ has a response time of $\sim 27.8 \mathrm{~s}$. This enhanced response time may be a result of the extra heterogenous interface of $\mathrm{MoS}_{2} / \mathrm{MoO}_{\mathrm{x}} \mathrm{NR}$ and carbon black. The interface is not atomically smooth and thus results in delayed response time. In addition to this, long-term photo response was also checked for $\mathrm{MoS}_{2} / \mathrm{MoO}_{\mathrm{x}} \mathrm{NRs}$ in the presence of green and red light (figure S5). In both the cases, $\mathrm{MoS}_{2} / \mathrm{MoO}_{\mathrm{x}} \mathrm{NR}$ shows high photoresponse as excitation frequency for $\mathrm{MoS}_{2}$ matches in both the wavelengths. 


\section{c. Photo-Rechargeable Battery Construction and Performance:}

As mentioned before, the heterostructures of $2 \mathrm{D}$ materials show high energy capacity in $\mathrm{Li}^{+}$storage compared with their individual 2D counterparts. ${ }^{20}$ Herein, the conventional $\mathrm{Li}^{+}$ battery performance of $\mathrm{MoS}_{2} / \mathrm{MoO}_{\mathrm{x}} \mathrm{NR}$ was initially tested and compared with that of $\mathrm{MoO}_{\mathrm{x}} \mathrm{NR}$ and $\mathrm{MoS}_{2} \mathrm{NR}$ (figure S6 (a-c)). It is observed that the specific capacity obtained for $\mathrm{MoS}_{2} / \mathrm{MoO}_{\mathrm{x}}$ $\mathrm{NR}\left(600 \mathrm{mAh} \mathrm{g}^{-1}\right.$ for the second cycle) is always higher than that of $\mathrm{MoO}_{\mathrm{x}} \mathrm{NR}\left(250 \mathrm{mAh} \mathrm{g}^{-1}\right.$ for the second cycle) and $\mathrm{MoS}_{2} \mathrm{NR}\left(450 \mathrm{mAh} \mathrm{g}^{-1}\right.$ for the second cycle). This ensures a better charge storage capacity of the as prepared $\mathrm{MoS}_{2} / \mathrm{MoO}_{\mathrm{x}} \mathrm{NR}$ heterostructure when compared to $\mathrm{MoO}_{\mathrm{x}} \mathrm{NR}$ or $\mathrm{MoS}_{2} \mathrm{NR}$ alone in a conventional Li battery coin cell (figure S6 (d)).

The photo-rechargeability of the $\mathrm{MoS}_{2} / \mathrm{MoO}_{x} \mathrm{NR}$ in $\mathrm{Li}^{+}$battery was tested using a homebuilt photo-rechargeable battery (cell) setup (schematic and setup design are discussed in SI section-5 and figure S7). A light entering window is placed on the positive side while a lithium metal is placed at the negative side. To check the light assisted de-lithiation (or photo-charging) process of the $\mathrm{MoS}_{2} / \mathrm{MoO}_{\mathrm{x}} \mathrm{NR}$ electrode, the lithium half-cell was constructed showing the initial open circuit voltage $(\mathrm{OCV})$ of $3.1 \mathrm{~V}$. The cell was discharged in dark with $12 \mathrm{mAg}^{-}$ ${ }^{1}$ discharge current density (figure 3 (a), dark area). After a complete discharge (till it reaches $0.01 \mathrm{~V}$ ), the cell voltage was allowed to equilibrate (figure 3 (a), brown area) after the discharging. ${ }^{39}$ After the voltage stabilization (at $\sim 2.42 \mathrm{~V}$ ), a red LED light having a power density of $50 \mathrm{mWcm}^{-2}$ is turned on. The voltage enhancement is visible during the exposure of light as shown in figure 3 (a) (red area, enhanced up to $2.83 \mathrm{~V}$ within $4.7 \mathrm{~h}$, in situ photo- 
charging with light is shown in the supporting information video). This rise in the voltage is due to the light assisted de-lithiation or photo-charging of $\mathrm{MoS}_{2} / \mathrm{MoO}_{\mathrm{x}} \mathrm{NR}$ electrode. To further confirm the effect of photo-charging on $\mathrm{Li}$ insertion and de-insertion in $\mathrm{MoS}_{2} / \mathrm{MoO}_{\mathrm{x}} \mathrm{NR}$ electrode, cyclic voltammetry (CV) experiment was performed with Li-ion half-cells of $\mathrm{MoS}_{2} / \mathrm{MoO}_{\mathrm{x}} \mathrm{NR}$ electrode with and without the exposure of light. The cyclic voltammogram (CV) was recorded in the range of $0.1-3.35 \mathrm{~V} v s \mathrm{Li} / \mathrm{Li}^{+}$at a scan rate of $1 \mathrm{mV} / \mathrm{s}$ (figure $3(\mathrm{~b})$ ). In the cathodic region, the peaks at $2.3 \mathrm{~V}$ and $1.85 \mathrm{~V}$ are attributed to $\mathrm{Li}^{+}$insertion in $\mathrm{MoO}_{3}$ and $\mathrm{MoS}_{2}$, respectively. ${ }^{40}$ Besides this, the peak at $0.6 \mathrm{~V}$ is related to the decomposition of the discharged species $\left(\mathrm{Li}_{\mathrm{x}} \mathrm{MoO}_{3}\right.$ and $\left.\mathrm{Li}_{\mathrm{x}} \mathrm{MoS}_{2}\right)$ and formation of the solid electrolyte interphase (SEI). Further in the anodic region, the broad peak in the range of $1.4-2.2 \mathrm{~V}$ is related to the delithiation of $\mathrm{Li}_{x} \mathrm{MoS}_{2}$, oxidation of $\mathrm{Mo}$ to $\mathrm{MoS}_{2}$ and $\mathrm{MoO}_{3}$, and oxidation of $\mathrm{Li}_{2} \mathrm{~S}$ to sulphur and polysulfides. ${ }^{40}$ All these characteristic peaks were observed in the presence of light as well. On the light exposure, the relative enhancements in the current density for all the redox peaks were observed. This can be attributed to the photo-current generated in the $\mathrm{MoS}_{2} / \mathrm{MoO}_{\mathrm{x}} \mathrm{NR}$ electrode in the presence of light.

To confirm the light assisted de-lithiation in a lithiated $\mathrm{MoS}_{2} / \mathrm{MoO}_{\mathrm{x}}$ NR electrode, Raman spectra of the electrodes before and after light assisted de-lithiation were compared. Due to the lithiation in the $\mathrm{MoS}_{2}$ of $\mathrm{MoS}_{2} / \mathrm{MoO}_{\mathrm{x}} \mathrm{NR}$, the phase transition of $2 \mathrm{H}$ phase to the $1 \mathrm{~T}$ phase (figure 3 (c)) was happened. Further, the disappearance of $\mathrm{B}_{2 \mathrm{~g}}$ mode of $\mathrm{MoO}_{\mathrm{x}} \mathrm{NR}$ is also observed because structure becomes highly disordered. ${ }^{15}$ A slight shift in the $\mathrm{E}_{\mathrm{g}}$ and $\mathrm{A}_{1 \mathrm{~g}}$ Raman modes can also be seen. ${ }^{41}$ On de-lithiation due to the photo-charging process, the $1 \mathrm{~T}$ phase is found to be disappeared and so as the shift in $\mathrm{E}_{\mathrm{g}}$ and $\mathrm{A}_{1 \mathrm{~g}}$ modes of vibration (figure 3 (c)). As the holes are generated only in $\mathrm{MoS}_{2}$, de-lithiation doesn't seem to be happened in the $\mathrm{MoO}_{\mathrm{x}}$ and 
hence the $\mathrm{B}_{2 \mathrm{~g}}$ Raman modes of $\mathrm{MoO}_{\mathrm{x}}$ is not restored after de-lithiation. But this issue can be addressed by electrochemical charging of the cell in definite intervals, as shown in the supporting information.
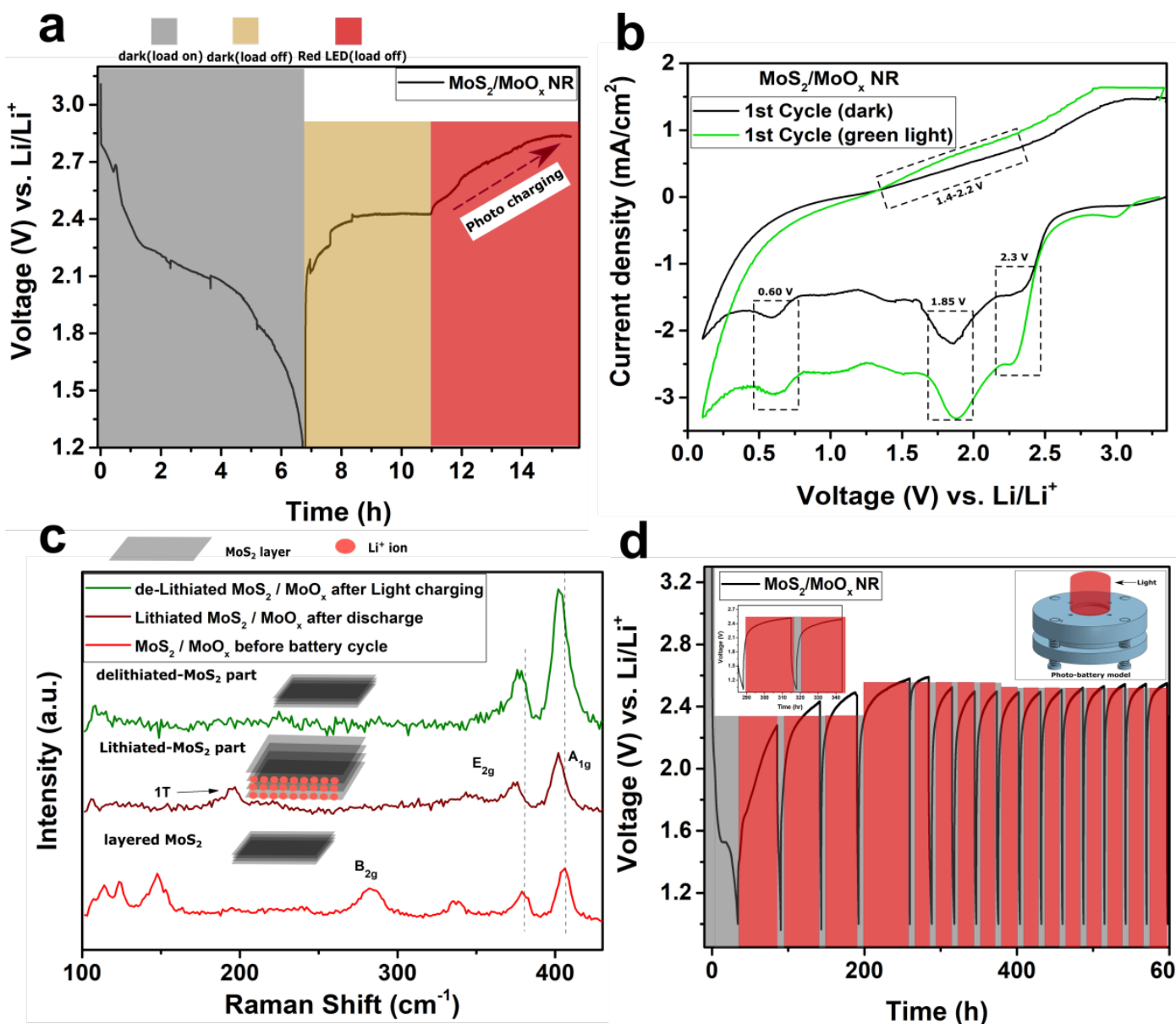

d
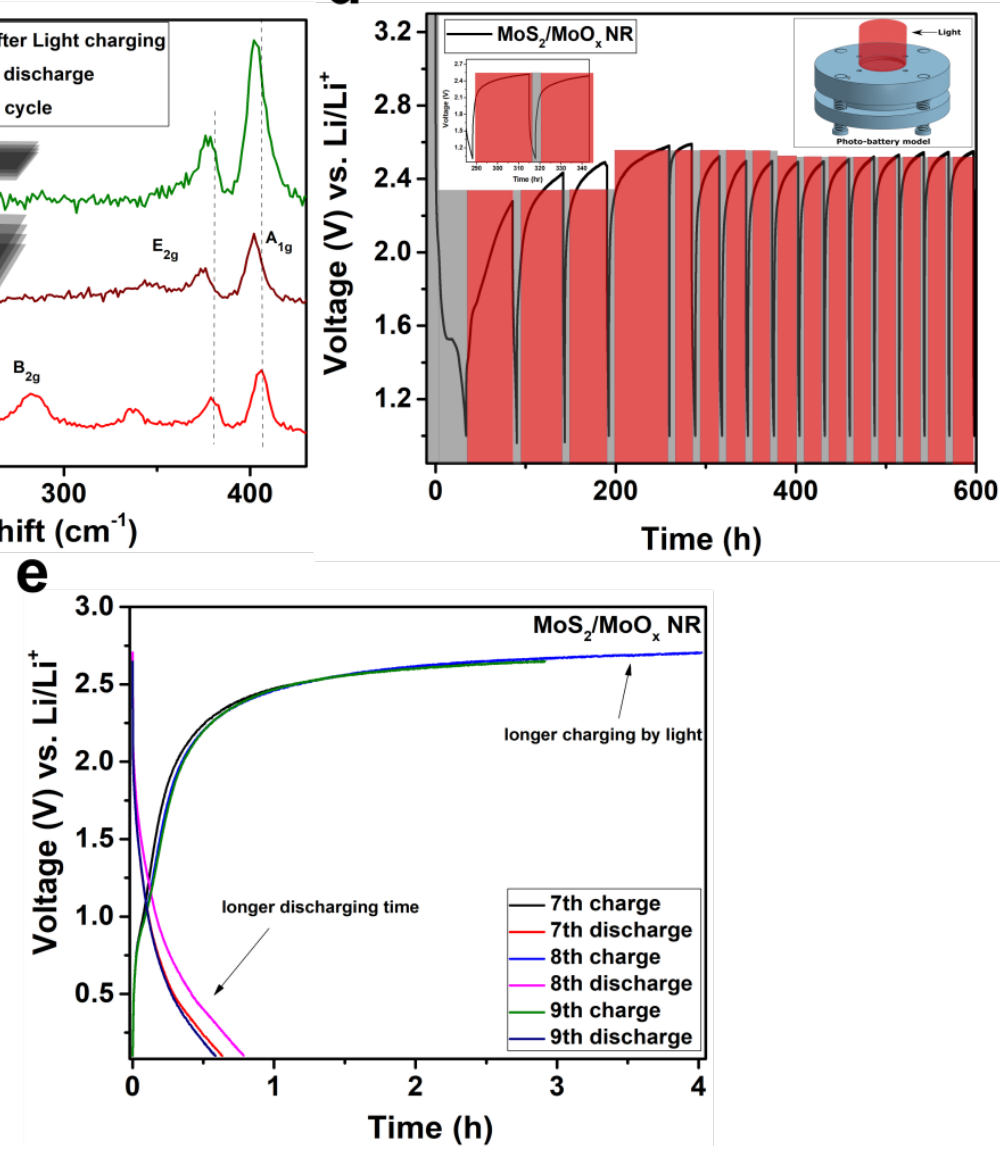
Figure 3. Photo charging and phase change traces by Raman spectroscopy: (a) Discharging in dark by constant current load (black area) followed by voltage equilibration (yellow area) and photo charging (red area). (b) Comparison of cyclic voltammogram (CV) of $\mathrm{MoS}_{2} / \mathrm{MoO}_{\mathrm{x}} \mathrm{NR}$ electrodes (with Lithium metal as counter electrode) in dark and light at a scan rate of $1 \mathrm{mV} / \mathrm{s}$. (c) Comparison of the phase changes in $\mathrm{MoS}_{2}(2 \mathrm{H}-1 \mathrm{~T}-2 \mathrm{H})$ before lithiation (red curve), after lithiation (brown curve), and after light-assisted de-lithiation (green curve) by Raman spectroscopy. (d) Long-term photo-battery cycling done at constant current for discharge and photo-assisted charge. (e) Comparison of the discharge time by varying photo-charging duration.

The long-term cyclability of this photo-rechargeable cell system is shown in figure 3 (d) (photographs of the setup in SI, figure S8). The discharge capacity is decreased from $120 \mathrm{mAhg}^{-1}$ for first light assisted discharge to $40 \mathrm{mAhg}^{-1}$ for $10^{\text {th }}$ discharge. This charge storage capacity loss within few cycles is due to the fact that lithiation in $\mathrm{MoO}_{\mathrm{x}}$ is not recovered during photocharging because the hole generation happens in $\mathrm{MoS}_{2}$ only, but can be recovered by electrochemical charging in definite intervals (as discussed before). Furthermore, during this long cycling, the discharge time always varies directly with charge time in the presence of light (figure 3 (e)). This confirms that the total charge capacity, hence the discharge capacity, depends on the duration of light exposure (number of photons absorbed) in the photo assisted de-lithiation process in the $\mathrm{MoS}_{2} / \mathrm{MoO}_{\mathrm{x}} \mathrm{NR}$ electrode.

The discharge of the cell is also checked in the presence of light and compared with that in the dark. Due to the competitive charging process, the discharge capacity is found to be increased from $69 \mathrm{mAh} \mathrm{g}^{-1}$ in dark to $162 \mathrm{mAh} \mathrm{g}^{-1}$ in the presence of light (figure 4 (a)). This 
enhancement in the energy efficiency in the presence of light shows the performance of $\mathrm{MoS}_{2} / \mathrm{MoO}_{\mathrm{x}}$ NR electrode based photoelectrodes (figure 4 (b), details in SI, section-6).
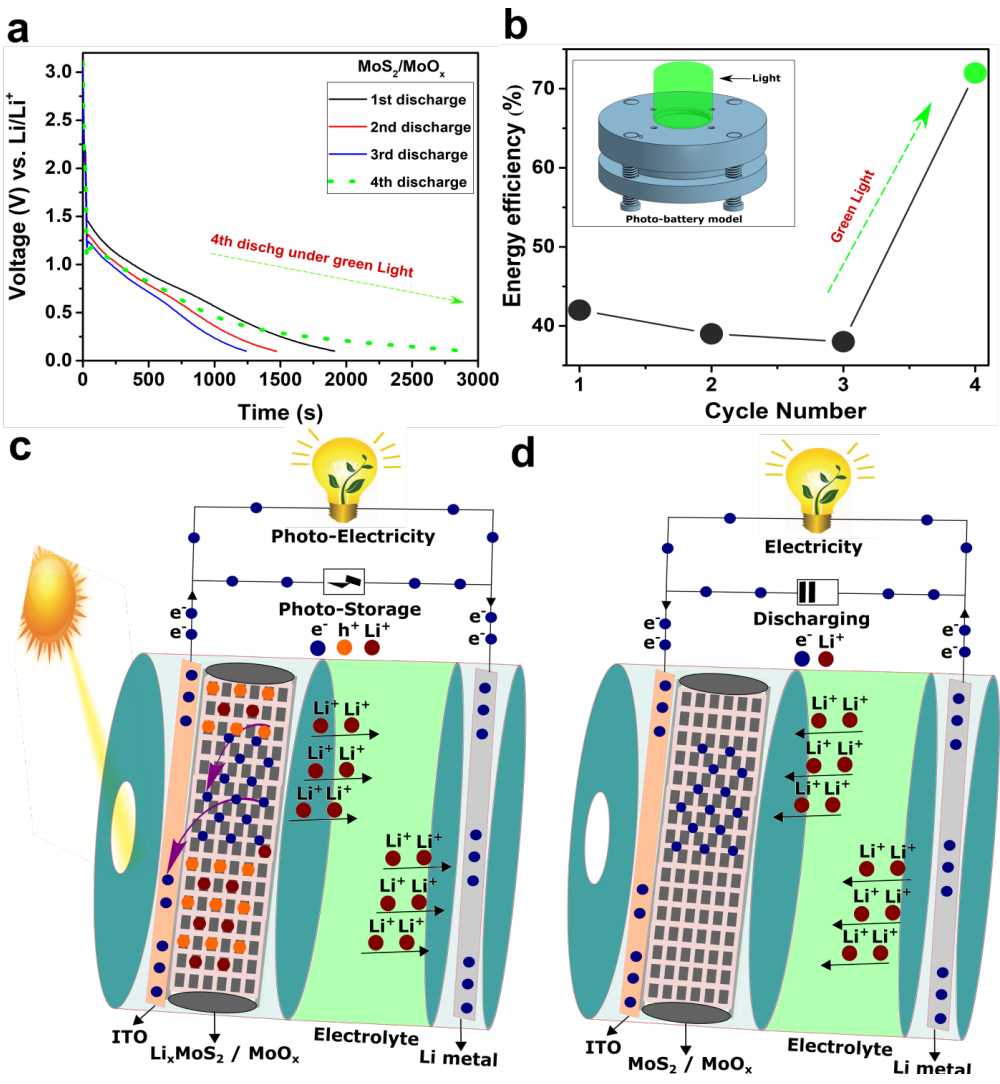

Figure 4. (a) Competitive photo-charging during the discharge of the battery with $\mathrm{MoS}_{2} / \mathrm{MoO}_{\mathrm{x}}$ photo-electrode. (b) Energy efficiency (\%) for discharge in dark at constant current load for three cycles and discharge in green LED during the fourth cycle (inset photo-battery model with a light window). (c) Schematic illustrations of simultaneous photo-storage and photo-electricity 
generation by a single nanostructured type II semiconductor heterostructure of $\mathrm{MoS}_{2} / \mathrm{MoO}_{\mathrm{x}} \mathrm{NR}$ with Li metal as the counter electrode in a two-electrode photo-rechargeable battery. (d) Schematic showing the use of stored electrochemical energy in the absence of light.

Finally, the mechanism of photo-charging on the $\mathrm{MoS}_{2} / \mathrm{MoO}_{\mathrm{x}} \mathrm{NR}$ based photoelectrode for $\mathrm{Li}^{+}$cell is proposed here. Semiconductor $\mathrm{I}\left(\mathrm{MoS}_{2}\right)$ acts as both lithium storage and light absorbing material where photoelectrons are generated on light exposure. While, semiconductor II $\left(\mathrm{MoO}_{\mathrm{x}}\right)$ acts as a separator electrode of electron-hole pairs generated in $\mathrm{MoS}_{2}$. When light falls on a lithiated $\mathrm{MoS}_{2} / \mathrm{MoO}_{\mathrm{x}} \mathrm{NR}$ via transparent ITO coated glass electrode (figure 4 (c)), the holes accumulated in $\mathrm{MoS}_{2}$ pushes $\mathrm{Li}^{+}$ions towards the anode where they get neutralized by photoelectrons. As in a conventional $\mathrm{Li}$ ion battery, $\mathrm{Li}$ metal spontaneously oxidize to $\mathrm{Li}^{+}$ions during discharging and the generated $\mathrm{Li}^{+}$ions get intercalated in the $\mathrm{MoS}_{2} / \mathrm{MoO}_{\mathrm{x}} \mathrm{NR}$ (figure 4 (d)).

In conclusion, a two-electrode photo-rechargeable $\mathrm{Li}^{+}$battery (single cell) is demonstrated here. A type-II semiconductor heterostructure having staggered optical band gap alignment formed due to the in-plane bonding of $\mathrm{MoS}_{2}$ and $\mathrm{MoO}_{\mathrm{x}}$ is used as a photo-electrode for battery recharging. After establishing the structure, photoelectron generation, and charge separation in this heterostructure $\left(\mathrm{MoS}_{2} / \mathrm{MoO}_{\mathrm{x}}\right)$, construction of a solar battery of $\mathrm{MoS}_{2} / \mathrm{MoO}_{\mathrm{x}}$ with Li metal as the other electrode shows the potential of such semiconductors-based stable ( $>15$ cycles are shown here) electrodes in photo-recharging, contrary to other unstable electrodes in the present literature. In this cell, the discharge capacity is found to be increased from $69 \mathrm{mAh}$ $\mathrm{g}^{-1}$ in dark to $162 \mathrm{mAh} \mathrm{g}^{-1}$ in the presence of light, indicating the enhancement in the energy efficiency to $\sim 70 \%$ in light (green, $50 \mathrm{~mW}$ ). This opens up the potential in developing 
semiconductor heterostructures based novel photo-electrode designs in solar batteries, where they can ensure high light-matter interaction with small exciton binding energy in comparison to that in organic materials, high electrolyte stability, large metal ion intercalation area, and hence high energy efficient, high-capacity solar batteries.

\section{Acknowledgements:}

Authors thank the support of the Department of Atomic Energy, Government of India, under Project Identification No. RTI 4007. Authors thank Dr. Pranav R. Shirhatti for his valuable suggestions on designing and understanding the photo-battery model.

\section{Supporting Information:}

The details of the coin cell performance, materials synthesis, photo-rechargeable cell design, STEM-HAADF images, SEM images, EDS mapping etc. are available in the supporting information. 


\section{References}

1. Vega-Garita, V.; Hanif, A.; Narayan, N.; Ramirez-Elizondo, L.; Bauer, P., Selecting a suitable battery technology for the photovoltaic battery integrated module. Journal of Power Sources 2019, 438, 227011.

2. $\mathrm{Xu}, \mathrm{J}$.; Chen, Y.; Dai, L., Efficiently photo-charging lithium-ion battery by perovskite solar cell. Nat Commun 2015, 6 (1), 1-7.

3. Li, Q.; Liu, Y.; Guo, S.; Zhou, H., Solar energy storage in the rechargeable batteries. Nano Today 2017, 16, 46-60.

4. Rizzo, G., Automotive applications of solar energy. IFAC Proceedings Volumes 2010, 43 (7), 174-185.

5. Klesh, A. T.; Kabamba, P. T., Solar-powered aircraft: Energy-optimal path planning and perpetual endurance. Journal of guidance, control, and dynamics 2009, 32 (4), 1320-1329.

6. Vertat, I.; Vobornik, A., Efficient and reliable solar panels for small CubeSat picosatellites. International Journal of Photoenergy 2014, 2014.

7. Hodes, G.; Manassen, J.; Cahen, D., Photoelectrochemical energy conversion and storage using polycrystalline chalcogenide electrodes. Nature 1976, 261 (5559), 403-404.

8. Monassen, J.; Hodes, G.; Cahen, D., Photoelectrochemical Energy Conversion and Storage: The Polycrystalline Cell with Different Storage Modes. J Electrochem Soc 1977, 124 (4), 532.

9. Paolella, A.; Faure, C.; Bertoni, G.; Marras, S.; Guerfi, A.; Darwiche, A.; Hovington, P.; Commarieu, B.; Wang, Z.; Prato, M., Light-assisted delithiation of lithium iron phosphate nanocrystals towards photo-rechargeable lithium ion batteries. Nat Commun 2017, 8 (1), 1-10.

10. Ahmad, S.; George, C.; Beesley, D. J.; Baumberg, J. J.; De Volder, M., Photorechargeable organo-halide perovskite batteries. Nano letters 2018, 18 (3), 1856-1862.

11. Kato, K.; Puthirath, A. B.; Mojibpour, A.; Miroshnikov, M.; Satapathy, S.; Thangavel, N. K.; Mahankali, K.; Dong, L.; Arava, L. M. R.; John, G., Light-Assisted Rechargeable Lithium Batteries: Organic Molecules for Simultaneous Energy Harvesting and Storage. Nano letters 2021, 21 (2), 907-913.

12. Hu, Z.; Liu, Q.; Chou, S.-L.; Dou, S.-X., Two-dimensional material-based heterostructures for rechargeable batteries. Cell Reports Physical Science 2021, 100286.

13. Rasmussen, F. A.; Thygesen, K. S., Computational 2D materials database: electronic structure of transition-metal dichalcogenides and oxides. The Journal of Physical Chemistry C 2015, 119 (23), 13169-13183.

14. Suslov, E. A.; Bushkova, O. V.; Sherstobitova, E. A.; Reznitskikh, O. G.; Titov, A. N., Lithium intercalation into TiS 2 cathode material: phase equilibria in a Li-TiS 2 system. Ionics 2016, 22 (4), 503-514.

15. Lee, S. H.; Kim, Y. H.; Deshpande, R.; Parilla, P. A.; Whitney, E.; Gillaspie, D. T.; Jones, K. M.; Mahan, A. H.; Zhang, S.; Dillon, A. C., Reversible lithium-ion insertion in molybdenum oxide nanoparticles. Advanced Materials 2008, 20 (19), 3627-3632.

16. Kim, H.-S.; Cook, J. B.; Lin, H.; Ko, J. S.; Tolbert, S. H.; Ozolins, V.; Dunn, B., Oxygen vacancies enhance pseudocapacitive charge storage properties of MoO 3- x. Nat Mater 2017, 16 (4), 454-460.

17. Stephenson, T.; Li, Z.; Olsen, B.; Mitlin, D., Lithium ion battery applications of molybdenum disulfide (MoS 2) nanocomposites. Energ Environ Sci 2014, 7 (1), 209-231. 
18. Park, J.; Kim, J.-S.; Park, J.-W.; Nam, T.-H.; Kim, K.-W.; Ahn, J.-H.; Wang, G.; Ahn, H.-J., Discharge mechanism of MoS2 for sodium ion battery: Electrochemical measurements and characterization. Electrochimica Acta 2013, 92, 427-432.

19. Ren, X.; Zhao, Q.; McCulloch, W. D.; Wu, Y., MoS 2 as a long-life host material for potassium ion intercalation. Nano Research 2017, 10 (4), 1313-1321.

20. Pomerantseva, E.; Gogotsi, Y., Two-dimensional heterostructures for energy storage. Nature Energy 2017, 2 (7), 1-6.

21. San Martín, S.; Rivero, M. J.; Ortiz, I., Unravelling the Mechanisms that Drive the Performance of Photocatalytic Hydrogen Production. Catalysts 2020, 10 (8), 901.

22. Wang, J.; Zhao, J.; Osterloh, F., Photochemical charge transfer observed in nanoscale hydrogen evolving photocatalysts using surface photovoltage spectroscopy. Energ Environ Sci 2015, 8 (10), 2970-2976.

23. Mahmood, N.; Hou, Y., Electrode nanostructures in lithium-based batteries. Advanced Science 2014, 1 (1), 1400012.

24. Li, H.; Yu, K.; Tang, Z.; Fu, H.; Zhu, Z., High photocatalytic performance of a type-II $\alpha-$ MoO 3@ MoS 2 heterojunction: From theory to experiment. Phys Chem Chem Phys 2016, 18 (20), 14074-14085.

25. Patel, S. K. S.; Dewangan, K.; Srivastav, S. K.; Verma, N. K.; Jena, P.; Singh, A. K.; Gajbhiye, N., Synthesis of $\alpha$-MoO3 nanofibers for enhanced field-emission properties. Adv. Mater. Lett. 2018, 9 (8), 585.

26. Li, B.; Jiang, L.; Li, X.; Ran, P.; Zuo, P.; Wang, A.; Qu, L.; Zhao, Y.; Cheng, Z.; Lu, Y., Preparation of monolayer MoS 2 quantum dots using temporally shaped femtosecond laser ablation of bulk MoS 2 targets in water. Sci Rep-Uk 2017, 7 (1), 1-12.

27. Golovynskyi, S.; Irfan, I.; Bosi, M.; Seravalli, L.; Datsenko, O. I.; Golovynska, I.; Li, B.; Lin, D.; Qu, J., Exciton and trion in few-layer MoS2: thickness-and temperature-dependent photoluminescence. Applied Surface Science 2020, 515, 146033.

28. Dieterle, M.; Weinberg, G.; Mestl, G., Raman spectroscopy of molybdenum oxides Part I. Structural characterization of oxygen defects in MoO 3- $x$ by DR UV/VIS, Raman spectroscopy and X-ray diffraction. Phys Chem Chem Phys 2002, 4 (5), 812-821.

29. Chen, Z.; Cummins, D.; Reinecke, B. N.; Clark, E.; Sunkara, M. K.; Jaramillo, T. F., Core-shell MoO3-MoS2 nanowires for hydrogen evolution: a functional design for electrocatalytic materials. Nano letters 2011, 11 (10), 4168-4175.

30. Zhang, C.; Wang, Z.; Bhoyate, S.; Morey, T.; Neria, B. L.; Vasiraju, V.; Gupta, G.; Palchoudhury, S.; Kahol, P.; Mishra, S., MoS2 decorated carbon nanofibers as efficient and durable electrocatalyst for hydrogen evolution reaction. c 2017, 3 (4), 33.

31. Muijsers, J.; Weber, T.; Vanhardeveld, R.; Zandbergen, H.; Niemantsverdriet, J., Sulfidation study of molybdenum oxide using MoO3/SiO2/Si (100) model catalysts and MoIV3-sulfur cluster compounds. Journal of Catalysis 1995, 157 (2), 698-705.

32. Wongkrua, P.; Thongtem, T.; Thongtem, S., Synthesis of h-and $\alpha-M o O 3$ by refluxing and calcination combination: Phase and morphology transformation, photocatalysis, and photosensitization. Journal of Nanomaterials 2013, 2013.

33. Visic, B.; Dominko, R.; Gunde, M. K.; Hauptman, N.; Skapin, S. D.; Remskar, M., Optical properties of exfoliated MoS 2 coaxial nanotubes-analogues of graphene. Nanoscale research letters 2011, 6 (1), 1-6. 
34. Jeon, J.; Jang, S. K.; Jeon, S. M.; Yoo, G.; Jang, Y. H.; Park, J.-H.; Lee, S., Layercontrolled CVD growth of large-area two-dimensional MoS 2 films. Nanoscale 2015, 7 (5), 1688-1695.

35. Bai, H.; Yi, W.; Li, J.; Xi, G.; Li, Y.; Yang, H.; Liu, J., Direct growth of defect-rich MoO 3 - $\mathrm{x}$ ultrathin nanobelts for efficiently catalyzed conversion of isopropyl alcohol to propylene under visible light. J Mater Chem A 2016, 4 (5), 1566-1571.

36. Krishna, A. G.; Ravikumar, R.; Kumar, T. V.; Ephraim, S. D.; Ranjith, B.; Pranoy, M.; Dola, S., Investigation and comparison of optical and raman bands of mechanically synthesised MoO3 nano powders. Materials Today: Proceedings 2016, 3 (1), 54-63.

37. Kaushik, V.; Wu, S.; Jang, H.; Kang, J.; Kim, K.; Suk, J. W., Scalable exfoliation of bulk MoS2 to single-and few-layers using toroidal taylor vortices. Nanomaterials 2018, 8 (8), 587.

38. SAKHONWASEE, S.; TUMMACHAI, K.; NIMNOY, N., Influences of LED light quality and intensity on stomatal behavior of three petunia cultivars grown in a semi-closed system. Environmental Control in Biology 2017, 55 (2), 93-103.

39. Hu, Y.; Iwata, G. Z.; Mohammadi, M.; Silletta, E. V.; Wickenbrock, A.; Blanchard, J. W.; Budker, D.; Jerschow, A., Sensitive magnetometry reveals inhomogeneities in charge storage and weak transient internal currents in Li-ion cells. Proceedings of the National Academy of Sciences 2020, 117 (20), 10667-10672.

40. Zhao, S.; Zha, Z.; Liu, X.; Tian, H.; Wu, Z.; Li, W.; Sun, L.-B.; Liu, B.; Chen, Z., CoreSheath Structured MoO3@ MoS2 Composite for High-Performance Lithium-Ion Battery Anodes. Energy \& Fuels 2020, 34 (9), 11498-11507.

41. Xia, J.; Wang, J.; Chao, D.; Chen, Z.; Liu, Z.; Kuo, J.-L.; Yan, J.; Shen, Z. X., Phase evolution of lithium intercalation dynamics in 2H-MoS 2. Nanoscale 2017, 9 (22), 7533-7540. 


\section{Supplementary Materials}

\section{Photo Rechargeable Li-Ion Batteries using Nanorod Heterostructure}

\section{Electrodes}

Amar Kumar ${ }^{\mathrm{a}}$, Pallavi Thakur ${ }^{\mathrm{a}}$, Rahul Sharma ${ }^{\mathrm{a}}$, Anand Puthirath ${ }^{\mathrm{b}}$, Pulickel M. Ajayan ${ }^{\mathrm{b}}$, and Tharangattu N. Narayanan ${ }^{\mathrm{a}^{*}}$

${ }^{a}$ Tata Institute of Fundamental Research - Hyderabad, Hyderabad, Telangana 500046, India

${ }^{\mathrm{b}}$ Department of Materials Science and Nano-engineering, Rice University, Houston, Texas 77005, United States

(Email*: tnn@tifrh.res.in)

\section{This file includes:}

Section1: Experimental section

- Materials \& Methods

- Preparation of Electrodes

- Characterization

Section 2: SEM, Raman spectroscopy, XPS, HAADF analysis and photoresponse $\mathrm{MoO}_{3}$, $\mathrm{MoS}_{2}$ and $\mathrm{MoS}_{2} / \mathrm{MoO}_{\mathrm{x}} \mathrm{NRs}$

- Figure S1: SEM and EDS mapping of $\mathrm{MoO}_{3}, \mathrm{MoS}_{2} / \mathrm{MoO}_{\mathrm{x}}$ and $\mathrm{MoS}_{2} \mathrm{NR}$

- Figure S2: Raman spectroscopy analysis for $\mathrm{MoS}_{2} / \mathrm{MoO}_{x} \mathrm{NR}$

- Figure S3: High resolution XPS spectra for $\mathrm{MoO}_{3}, \mathrm{MoS}_{2} / \mathrm{MoO}_{x}$ and $\mathrm{MoS}_{2} \mathrm{NR}$

- Figure S4: HAADF-STEM imagesand elemental mapping of $\mathrm{MoS}_{2} / \mathrm{MoO}_{\mathrm{x}} \mathrm{NR}$ and $\mathrm{MoS}_{2} \mathrm{NR}$ 
Section 3: Band structure of $\mathrm{MoO}_{3}, \mathrm{MoS}_{2}$ and $\mathrm{MoS}_{2} / \mathrm{MoO}_{\mathrm{x}}$

- Figure S5: Photo-response of $\mathrm{MoS}_{2} / \mathrm{MoO}_{\mathrm{x}} \mathrm{NR}$ in Red and Green LED

Section 4: Conventional Li-ion battery performance of MoS2 / MoOx NR

- Figure S6: Conventional $\mathrm{Li}^{+}$-ion battery performance of $\mathrm{MoO}_{3}, \mathrm{MoS}_{2} / \mathrm{MoO}_{\mathrm{x}}$ and $\mathrm{MoS}_{2} \mathrm{NR}$

Section 5: Photo-rechargeable battery model and assembly process

- Figure S7: Schematic of photo-rechargeable model

- Figure S8: Photograpgh of working photo-rechargeable battery

Section 6: Energy efficiency calculation

Section1: Experimental section

- Materials \& Methods:

\section{Materials: -}

Ammonium molybdatetetrahydrate (SRL), Nitric acid (Sigma-Aldrich), Sulphur (SigmaAldrich), Lithium hexa fluoro phoshphate in EC/EMC solvent (SigmaAldrich), ITO coated glass $25 \mathrm{~mm} \mathrm{x}$ $25 \mathrm{~mm}$ (Sigma-Aldrich)

\section{Methods:}

Chemical Synthesis: Firstly, $\mathrm{MoO}_{3}$ NRare synthesised by hydrothermal process. ${ }^{1}$ For that $1.0 \mathrm{~g}$ Ammonium molybdatetetrahydrate was dissolved in $80 \mathrm{ml}$ deionized water. Then, $6 \mathrm{ml}$ of $65 \%$ nitric acid was slowly added in the above solution. After 30 minutes of magnetic stirring, the above solution was transferred in a $100 \mathrm{ml}$ Teflon autoclave and heated at $180^{\circ} \mathrm{C}$ for $12 \mathrm{~h}$. After this, the solution is kept to cool down in room temperature. The obtained white compound was washed by deionised water and ethanol for many times and then dried at $60^{\circ} \mathrm{C}$ in dry oven. The growth $\mathrm{MoO}_{3}$ is $\alpha$ type, Mechanism involve in this can be formulated as in equation 1 to 3 .

$$
\begin{aligned}
& \mathrm{Mo}_{7} \mathrm{O}_{24}{ }^{6-}+6 \mathrm{H}^{+}+11 \mathrm{H}_{2} \mathrm{O} \rightarrow 7 \mathrm{MoO}_{3} \cdot 2 \mathrm{H}_{2} \mathrm{O} \\
& \mathrm{MoO}_{3} \cdot 2 \mathrm{H}_{2} \mathrm{O} \rightarrow \alpha-\mathrm{MoO}_{3} \cdot \mathrm{H}_{2} \mathrm{O}+\mathrm{H}_{2} \mathrm{O} \\
& \alpha-\mathrm{MoO}_{3} \cdot \mathrm{H}_{2} \mathrm{O} \rightarrow \alpha-\mathrm{MoO}_{3}+\mathrm{H}_{2} \mathrm{O}
\end{aligned}
$$


Further, to synthesize $\mathrm{MoS}_{2} / \mathrm{MoO}_{x}$ NR heterostructure, $\mathrm{MoS}_{2}$ growth was done on $\mathrm{MoO}_{3}$ by CVD in two zone furnaces. For deposition, a glass tube with sulphur powder as a sulphur source is heated in the first zone at $230^{\circ} \mathrm{C}$ while $\mathrm{MoO}_{3} \mathrm{NR}$ is kept in the second zone at $450^{\circ} \mathrm{C}$ with 20 minutes ramping and 5-minute growth time. To maintain the inert environment, a continuous flow of $\mathrm{N}_{2}$ gas at $85 \mathrm{SCCM}$ is allowed to pass. Further, for comparison $\mathrm{MoS}_{2} \mathrm{NR}$ were also synthesized with growth time of 20 minutes in the same environment.

\section{- Preparation of Electrodes:}

For electrode fabrication,the sample was mixed with $10 \%$ carbon black and $10 \%$ PVDF binder. Mixed well in NMP solvent and dropcasted on ITO coated glass. The coating was further dried at $80^{\circ} \mathrm{C}$ for $4 \mathrm{hr}$.

\section{- Characterisation:}

To determine vibrational modes of $\mathrm{MoS}_{2}$ and $\mathrm{MoO}_{3}$, Renishaw in Via Raman Microscope (532 nm excitation) was used. Further to know the surface topography and composition of the sample, scanning electron microscopy ((SEM)(FESEM) JEOL JSM-7200F) along with Energy Dispersive X-Ray Spectroscopy (EDS or EDX) was used. To identify elemental composition in material or on surface and chemical state we used PHI Quantera X-ray photoelectron spectrometer (Survey: pass energy, $140 \mathrm{eV}$, high-resolution spectra, $26 \mathrm{eV}$ ). Casaxps software was used for curve fitting. The nano-scale and atomic-scale structure of material was checked by Titan transmission electron microscope (TEM) (FEI Titan Themis 3 with acceleration voltage of $300 \mathrm{kV}$ ). Crystallinity of material was checked by X-ray diffraction (Bruker Tensor-27). UVVIS spectra (JASCO V-670) was recorded within 200 to $800 \mathrm{~nm}$ range.Photo activity waschecked in three electrode system with $\mathrm{Ag} / \mathrm{AgCl}$ reference and graphite as counter in Potentiostat, Biologic SP-300. For this, the sample was coated on glassy carbon and applied 0.3 $\mathrm{V}$ external bias in $0.1 \mathrm{M} \mathrm{Na}_{2} \mathrm{SO}_{4}$. Green and red LED light were used for regular on and off. 
Section 2: SEM, Raman spectroscopy, XPS, HAADF analysis and photoresponse ${\underline{\mathrm{MoO}_{3}}}_{3} \mathrm{MoS}_{2}$ and $\mathrm{MoS}_{2} / \mathrm{MoO}_{\mathrm{x}}$ NRs:

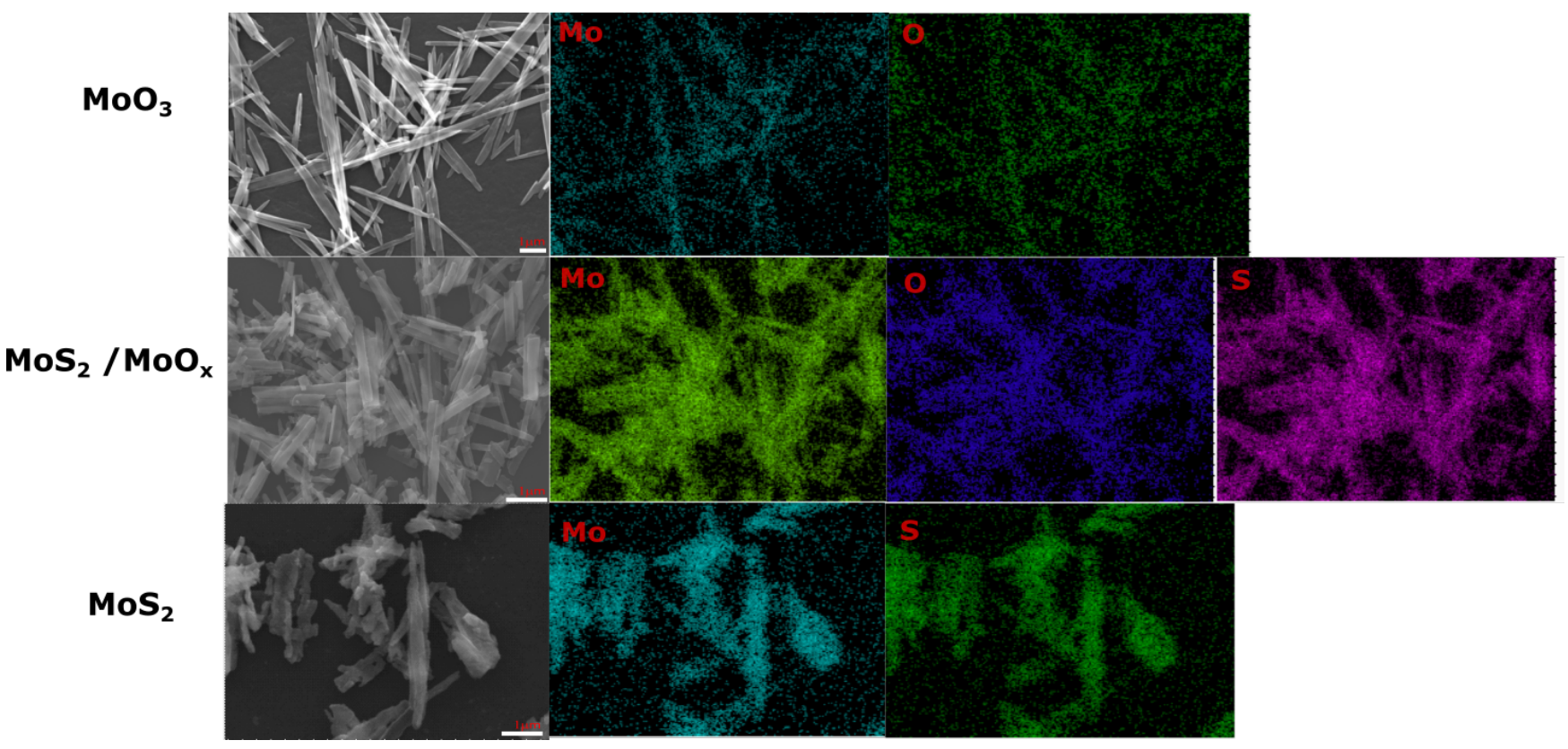

Figure S1. SEM and EDS mapping of $\mathrm{MoO}_{3}, \mathrm{MoS}_{2} / \mathrm{MoO}_{\mathrm{x}}$ and $\mathrm{MoS}_{2} \mathrm{NR}$ 

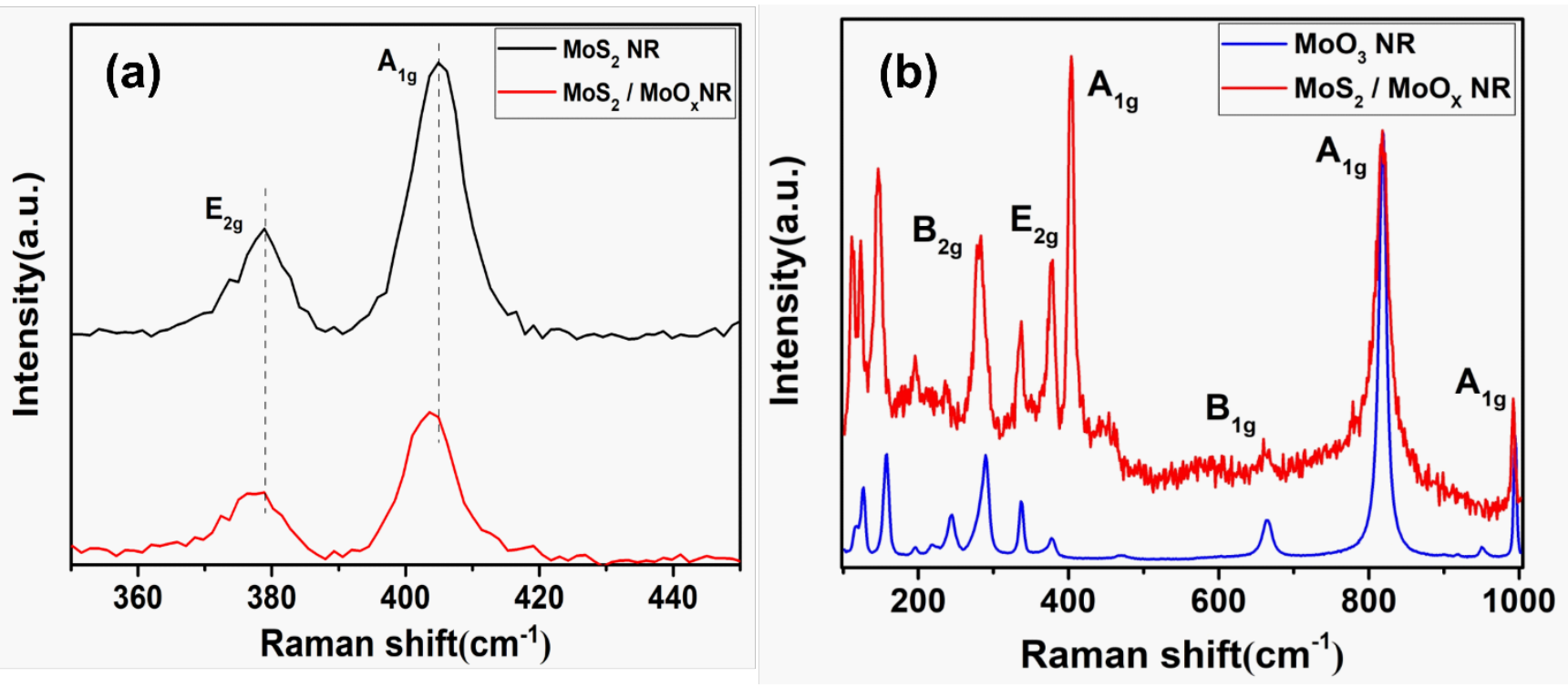

Figure S2. (a) Comparison of Raman shift of $\mathrm{MoS}_{2} / \mathrm{MoO}_{x}$ (red curve) and $\mathrm{MoS}_{2} \mathrm{NR}$ (black curve) (b) Raman modesbroadeningcomparison between of $\mathrm{MoS}_{2} / \mathrm{MoO}_{\mathrm{x}}$ and $\mathrm{MoO}_{3} \mathrm{NR}$ 
a
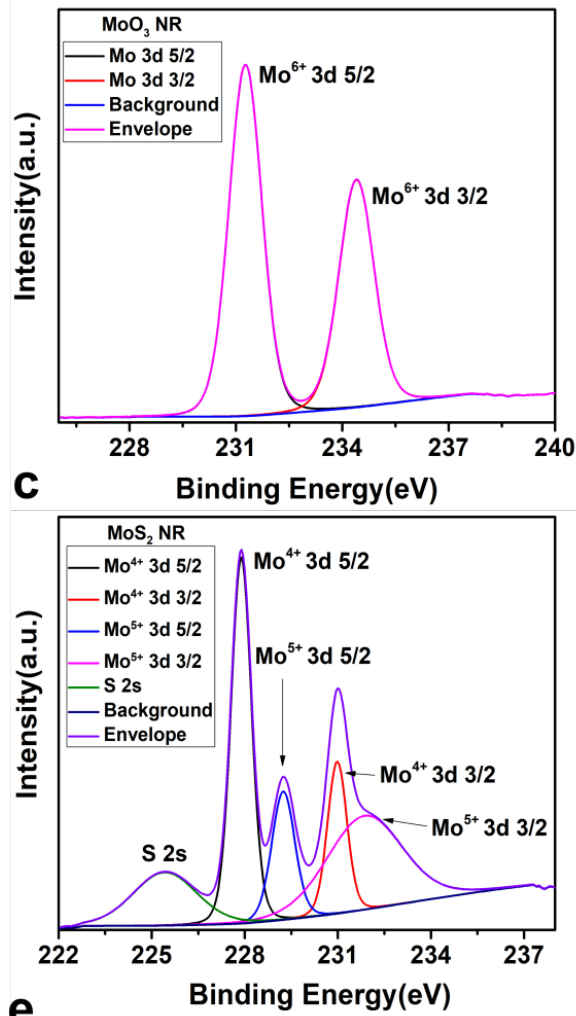

e

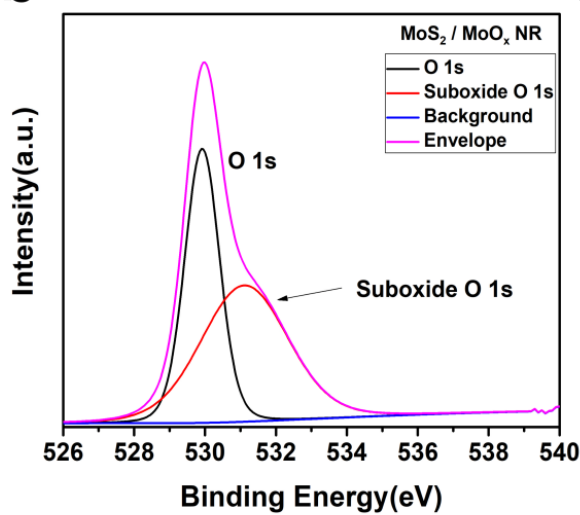

b
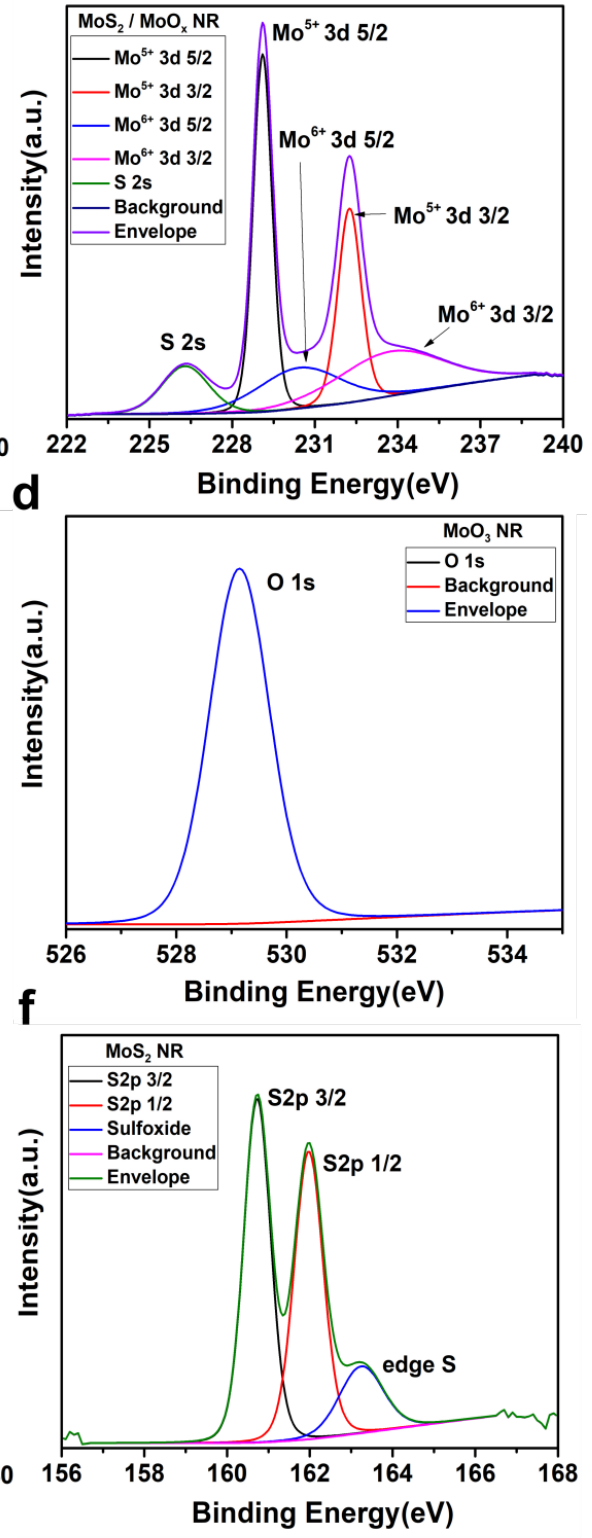

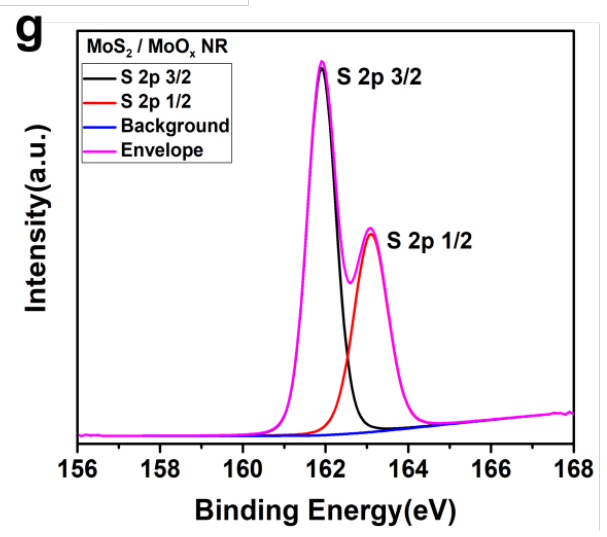

Figure S3:- High resolution XPS spectra of (a) $\mathrm{Mo} 3 \mathrm{~d}$ of $\mathrm{MoO}_{3} \mathrm{NR}$ (b) Mo 3d of $\mathrm{MoS}_{2} / \mathrm{MoO}_{\mathrm{x}} \mathrm{NR}$ (c) Mo $3 \mathrm{~d}$ of $\mathrm{MoS}_{2} \mathrm{NR}$ (d)O $1 \mathrm{~s}$ of $\mathrm{MoO}_{3} \mathrm{NR}(\mathrm{e}) \mathrm{O}$ 1s of $\mathrm{MoS}_{2} / \mathrm{MoO}_{\mathrm{x}} \mathrm{NR}(\mathrm{f}) \mathrm{S} 2 \mathrm{p}$ of $\mathrm{MoS}_{2} \mathrm{NR}(\mathrm{g}) \mathrm{S} 2 \mathrm{p}$ of $\mathrm{MoS}_{2} / \mathrm{MoO}_{\mathrm{x}} \mathrm{NR}$ 


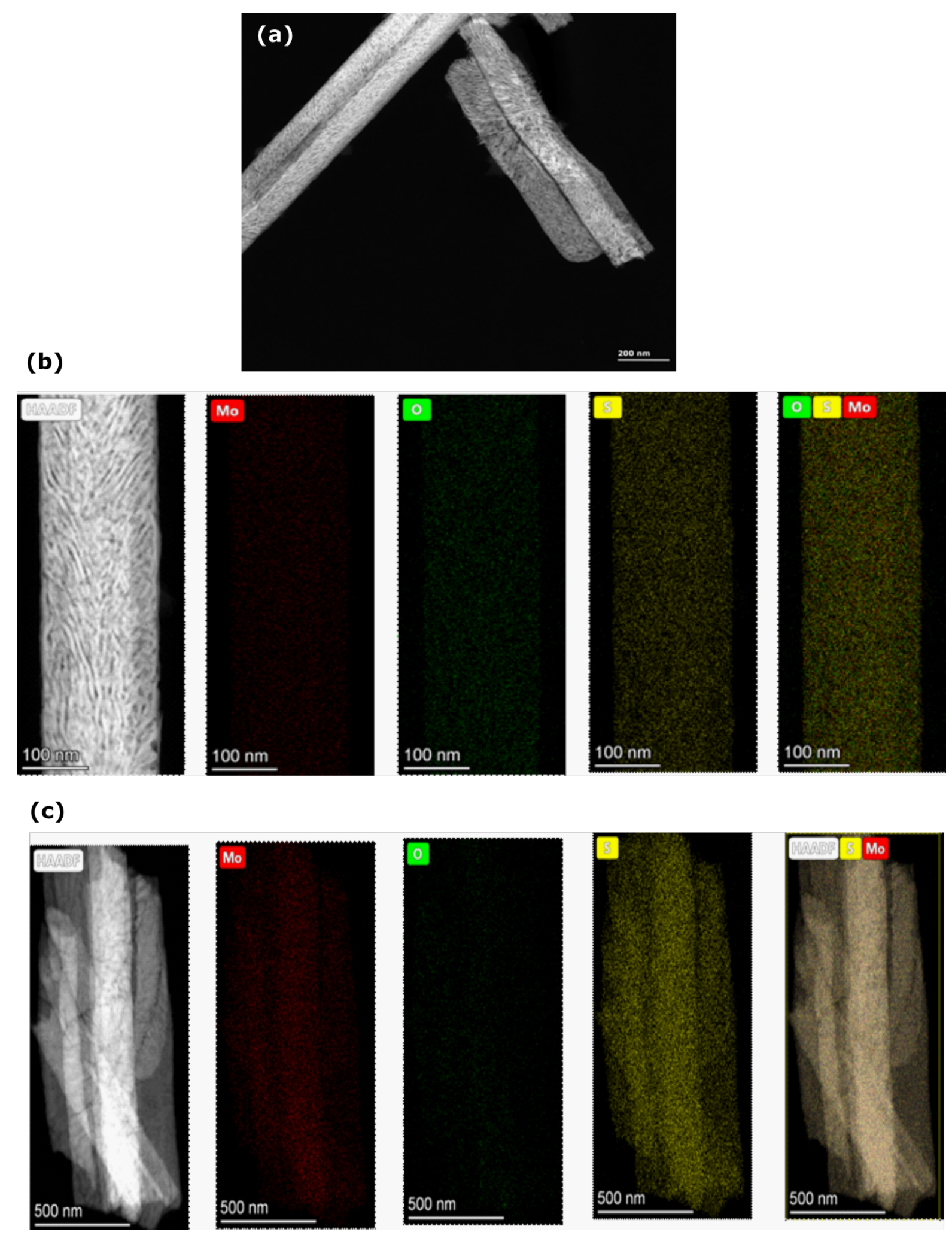

Figure S4. HAADF-STEM (a) image and elemental mapping (a-b) of $\mathrm{MoS}_{2} / \mathrm{MoO}_{x} \mathrm{NR}$ and $\mathrm{MoS}_{2} \mathrm{NR}$ 


\section{Section 3: Band structure of $\mathrm{MoO}_{3}, \mathrm{MoS}_{2}$ and $\mathrm{MoS}_{2} / \mathrm{MoO}_{\mathrm{x}}$ :}

DFT calculations of $\mathrm{MoO}_{3}$ shows that its band gap is $2.6 \mathrm{eV} .^{2}$ The Valence band (VB) of $\alpha$ $\mathrm{MoO}_{3}$ is mainly composed of $\mathrm{O} p$ states, while the Conduction band (CB) is formed mainly by Mo $4 \mathrm{~d}$ states. This shows the band position at $-9.66 \mathrm{eV}(\mathrm{VB})$ and $-6.96 \mathrm{eV}(\mathrm{CB})$. However, this get changed when $\mathrm{MoO}_{3}$ converts as $\mathrm{MoO}_{\mathrm{x}}$ to $-7.58 \mathrm{eV}$ (VB) and $-4.89 \mathrm{eV}$ (CB). ${ }^{3}$ Further, $\mathrm{MoS}_{2}$ VB mainly composed of $\mathrm{S} p$ states, while the Conduction band (CB) is formed mainly by Mo $4 \mathrm{~d}$ states. This shows band position at $-6.27 \mathrm{eV}(\mathrm{VB})$ and $-4.25 \mathrm{eV}(\mathrm{CB}){ }^{4}$ In $\mathrm{MoS}_{2} / \mathrm{MoO}_{\mathrm{x}}$ both the semiconductors make perfect staggered Type II Hetero-structure as shown figure 2 (a). When the incident light energy matches with $\mathrm{MoO}_{\mathrm{x}}$ band gap energy, the photons get absorbed. This excites the electrons from VB to CB. Similarly, electrons get excited in $\mathrm{MoS}_{2}$ too. However, due to staggered band alignment, electrons flow from $\mathrm{MoS}_{2}$ to $\mathrm{MoO}_{\mathrm{x}}$ and hole transfer from $\mathrm{MoO}_{3}$ to $\mathrm{MoS}_{2}$ VB. This makes the charge separation easier in $\mathrm{MoS}_{2} / \mathrm{MoO}_{x} \mathrm{NR}$.
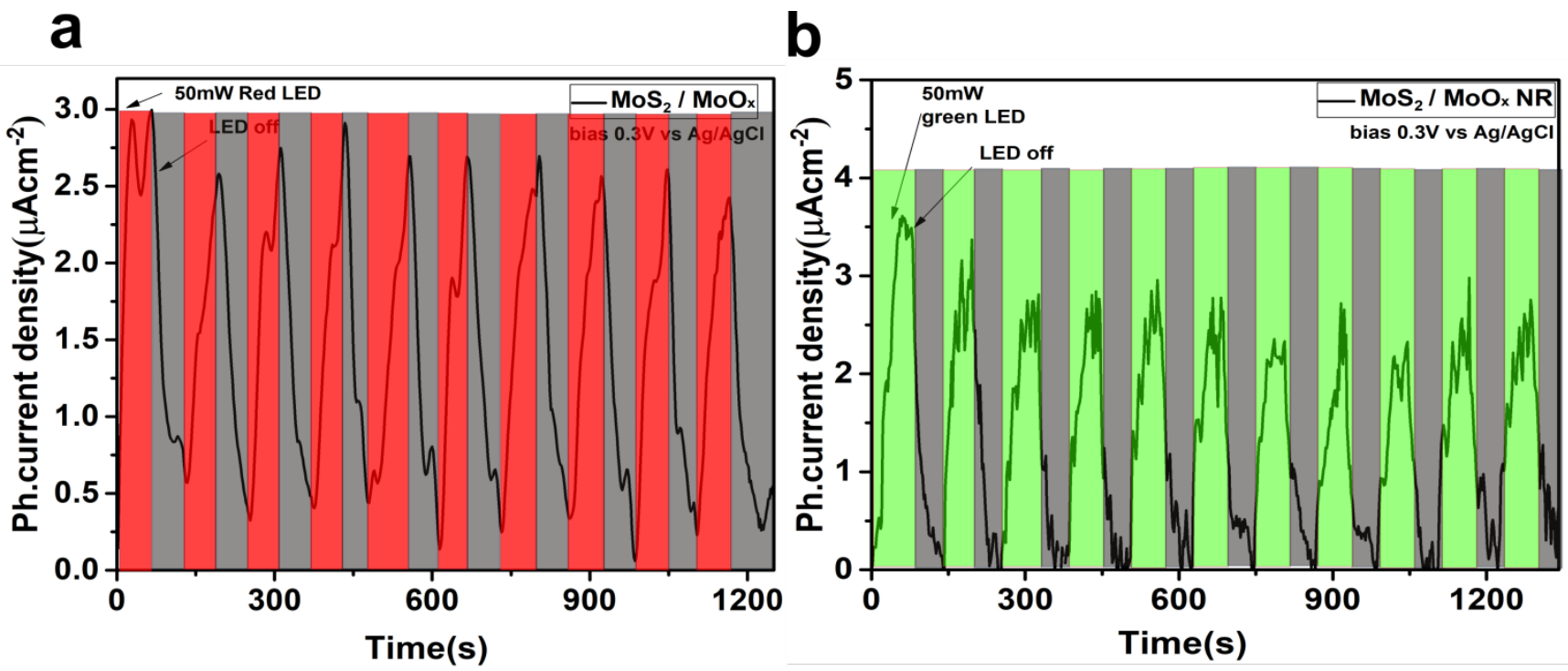

Figure S5. Photo-response of $\mathrm{MoS}_{2} / \mathrm{MoO}_{\mathrm{x}} \mathrm{NR}$ in (a) Red and (b) Green LED light 
Section 4: Conventional Li-ion battery performance of $\mathrm{MoS}_{2} / \mathrm{MoO}_{\mathrm{x}} \mathrm{NR}$ :

a

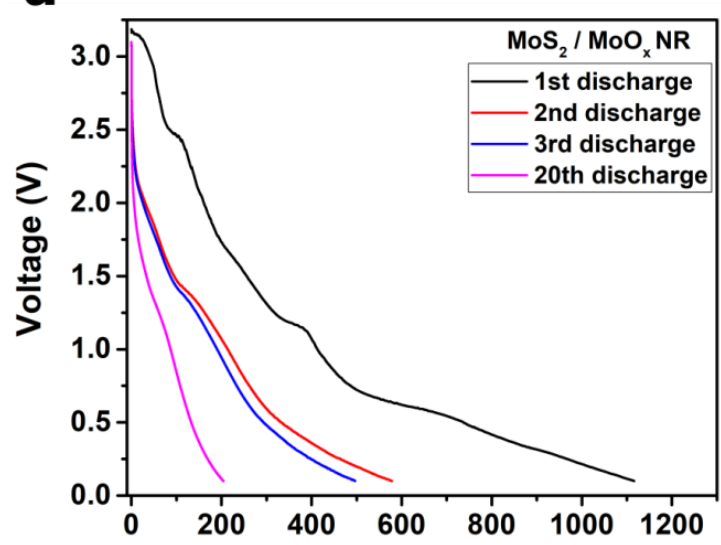

C Specific capacity (mAhg $\left.{ }^{-1}\right)$

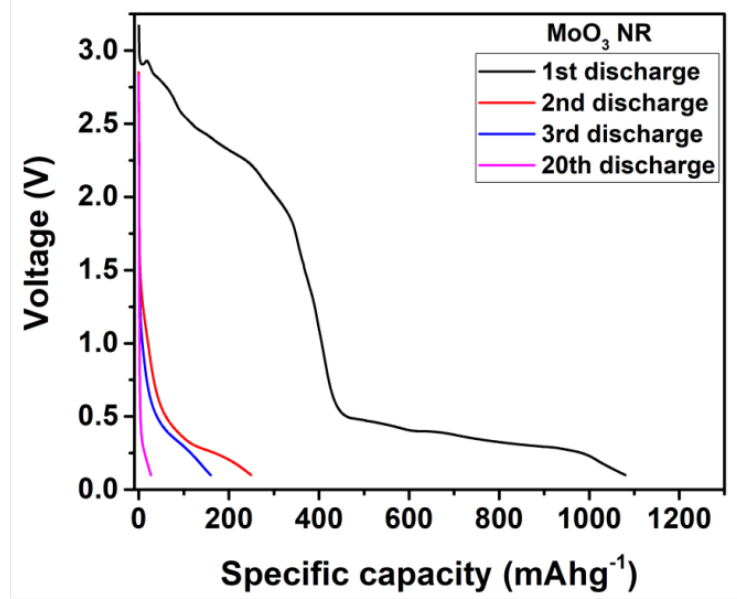

b

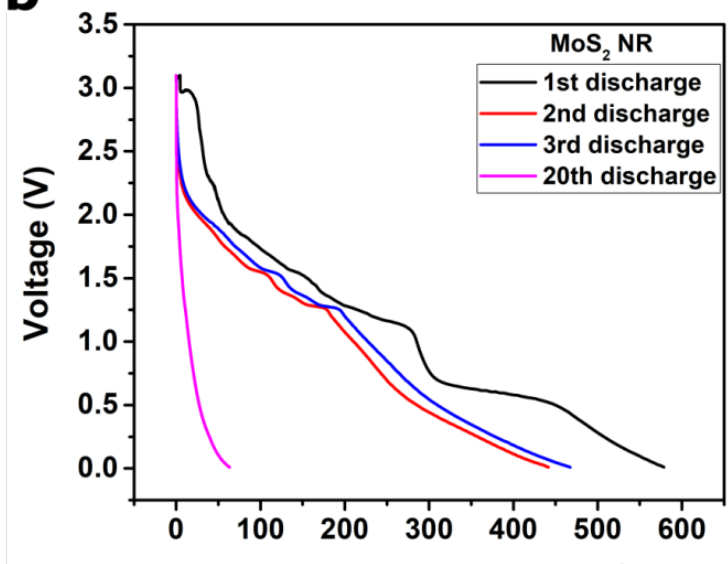

d Specific capacity (mAhg $\left.{ }^{-1}\right)$

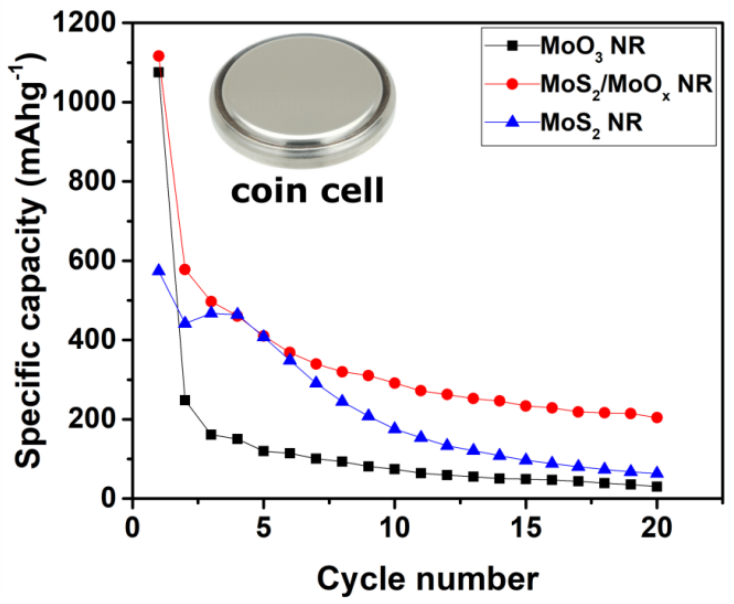

Figure S6. Conventional Li+ ion battery performance of (a) $\mathrm{MoS}_{2} / \mathrm{MoO}_{x} \mathrm{NR}$, (b) $\mathrm{MoS}_{2} \mathrm{NR}$, (c) $\mathrm{MoO}_{3} \mathrm{NR}$ (d) comparison of specific capacity for all electrodes. 


\section{Section 5:Photo-rechargeable battery model and assembly process:}

To perform experiments in ambient condition, a lab-made photo-rechargeable model with light window (figure S2) was used. The model positive case (I) is made of steel with $65 \mathrm{~mm}$ diameter and $16 \mathrm{~mm}$ thickness. A $4 \mathrm{~mm}$ thick O-ring with $20 \mathrm{~mm}$ diameter at $8.7 \mathrm{~mm}$ depth was placed in positive case (I) to make it completely air tight. A $17 \mathrm{~mm}$ diameter wide hole is made in positive case (I) as light window where $25 * 25 \mathrm{~mm}$ sample containing ITO coated glass (IV) is placed. Further, the conducting side of ITO is connected with positive case by copper foil (III), sealed by nut bolt using 31 outer and $17 \mathrm{~mm}$ inner diameter aluminum ring $(\mathrm{V})$. An O-ring was used in both side of ITO coated glass to seal air tight from bottom side and a Teflon separator (II) which separate positive and negative case. After that, separator (VI) lithium metal (VII), steel disc (VIII), one spring for better connectivity (IX), (45-35) $\mathrm{mm}$ diameter negative case $(\mathrm{X})$ were assembled as shown in figure S1. box.

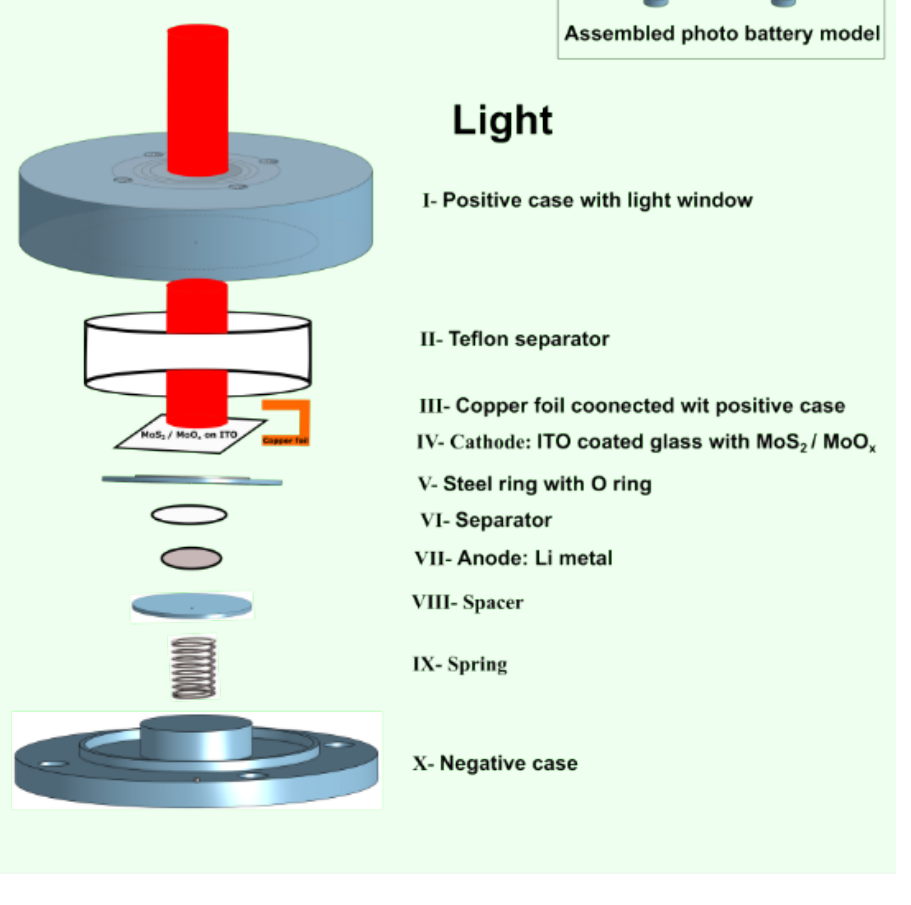

Figure S7. Schematic of photo-rechargeablehomebuilt battery model and its assembly model in inset

The assembly was made in an Ar filled glove. 
a

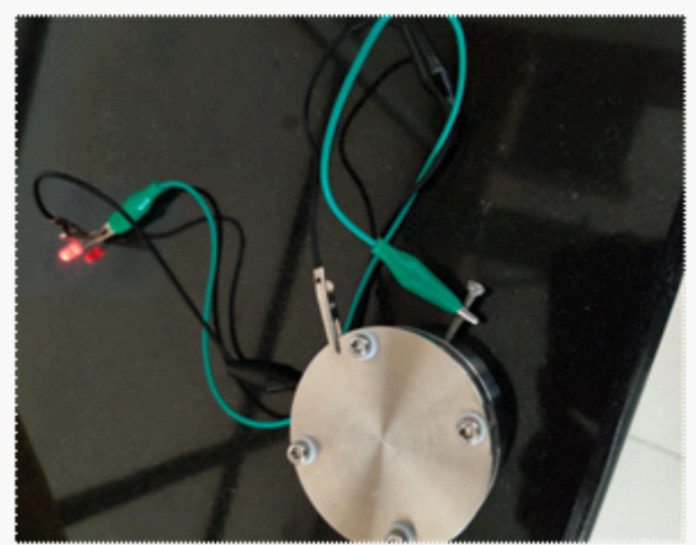

b

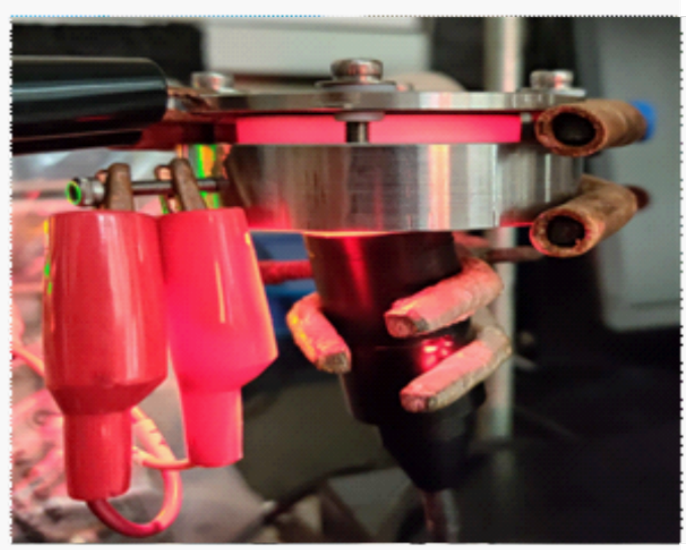

Figure S8. Figure S8. (a) Photograph of a working photo-chargeable cell on an LED load. (b) Photograph of the photo-charging of the cell by light.

\section{Section 6: Energy efficiency:}

Energy efficiency is calculatedby taking ratio of discharge and charge profile curves. During charging and discharging, it is evident that the voltage supplied for charging is higher than the cell voltage during the battery usage, and obviously, the energy efficiency is poor ${ }^{5}$ that we can see in figure 4 (b). 


\section{References}

1. Li, H.; Yu, K.; Tang, Z.; Fu, H.; Zhu, Z., High photocatalytic performance of a type-II $\alpha-$ MoO 3@ MoS 2 heterojunction: From theory to experiment. Phys Chem Chem Phys 2016,18 (20), 14074-14085.

2. Du, Y.; Peng, H. Y.; Mao, H.; Jin, K. X.; Wang, H.; Li, F.; Gao, X. Y.; Chen, W.; Wu, T., Evolution of the SrTiO3-MoO3 interface electronic structure: An in situ photoelectron spectroscopy study. Acs Appl Mater Inter 2015,7 (21), 11309-11314.

3. Butler, K. T.; Crespo-Otero, R.; Buckeridge, J.; Scanlon, D. O.; Bovill, E.; Lidzey, D.; Walsh, A., Band energy control of molybdenum oxide by surface hydration. Applied Physics Letters 2015,107 (23), 231605.

4. Lee, S.; Zhong, Z., Nanoelectronic circuits based on two-dimensional atomic layer crystals. Nanoscale 2014,6 (22), 13283-13300.

5. Eftekhari, A., Energy efficiency: a critically important but neglected factor in battery research. Sustainable Energy \& Fuels 2017,1 (10), 2053-2060. 